\title{
Determinants of Commercial Banks' Residual Profitability: An Industry Approach
}

\author{
Borja Amor Tapia \\ Universidad de Extremadura \\ Facultad de Estudios Empresariales y Turismo \\ Avda. de la Universidad s/n \\ 10071 Cáceres \\ Phone: (0034) 927257480 - Ext. 7919 \\ bamor@unex.es \\ María Teresa Tascón Fernández \\ Universidad de León \\ Facultad de Ciencias Económicas y Empresariales \\ Campus de Vegazana, $\mathrm{s} / \mathrm{n}$ \\ 24071 León \\ Phone: (0034) 987291737 \\ ddemtf@unileon.es \\ José Luis Fanjul Suárez \\ Universidad de León \\ Facultad de Ciencias Económicas y Empresariales \\ Campus de Vegazana, s/n \\ 24071 León \\ ddejfs@unileon.es
}

03 March 2006

*Comments are welcome

\begin{abstract}
:
This study contrasts the reliability of Abnormal ROE (residual income scaled by beginning-of-period book value of equity) estimates based on value drivers with a contextual approach in the commercial bank industry of the OECD countries. We identify the key theoretical variables from the banking and accounting literature and analyze the impact on the prediction of future abnormal ROEs. After regressing the following year's abnormal ROE on those variables, we verify that some of them, related to the competitiveness of banks and the accounting system, play a determinant role. Our evidence suggests that the identification of 'other information' factors, by a contextual approach, might improve the empirical use of the Ohlson Model in commercial banks, especially when they act in competitive environments and/or relevant intangibles are not captured by accounting.
\end{abstract}

KEYWORDS: residual income model, abnormal earnings, equity valuation, contextual approach, financial firms

JEL: D4, G12, M4 


\section{Introduction}

The evolution of ROE -and Abnormal ROE- plays a crucial role in the prediction of accounting variables needed as inputs in the equity discount models, mainly through what is called ratio-based earnings prediction. This kind of information is useful to evaluate the effects of accounting numbers over market values (a part of fundamental analysis $^{1}$ ). In this sense, our study may be considered directly related with market-based accounting research, and hence within the utilitarian paradigm.

As Kothari [2001: 173] says, "Given the historical nature of information in financial statements, meaningful fundamental analysis research requires accounting researchers to expand the definition of capital markets research to include research using forecasted earnings information for fundamental analysis. (...) Such research has to move beyond reporting descriptive statistics and evidence of the success of trading strategies into proposing theories and presenting empirical tests of the hypotheses derived from the theories".

This investigation is motivated both by the central role of expectations of book return on equity in the discounted residual income valuation model (e.g. see Feltham and Ohlson [1995]) and by prior empirical research that identifies a number of general factors correlated with future abnormal return on equity (e.g. see Cheng [2005]); industrial factors for non financial sectors (e.g. see Shores and Bowen [2002]); or industrial factors for the banking sector (e.g. see Kohlbeck et al. [2002], Begley et al. [2003], and Kohlbeck [2004]).

As a practical matter, the discounted residual income valuation model must be implemented by forecasting ROE and growth in book value over a finite horizon and also by the terminal value at the horizon [Beaver and Ryan, 2000: 145]. But some attempts to test the Ohlson Model $^{2}$, have produced contradictory results, what shows limitations in the empirical application of the model. In this sense, Beaver [1999] suggests that getting the drivers for residual income could help to obtain better estimations of value.

The purpose of this paper is to identify these value drivers for residual income in the banking industry. With this idea, we have investigated the effects of several factors over firm abnormal profitability using a data set comprising 3287 banks, located in 29 major OECD countries. The variables are observed annually over the period 1997 to 2003, together with a set of control variables that capture the impact of a variety of firm level, industry-level and macroeconomic variables. Methodologically, this paper attempts to unify the abnormal profitability strand (especially in banks) in the previous empirical studies and the banking industry profitability literature.

\footnotetext{
${ }^{1}$ Penman: "Fundamental analysis involves the determination of the value of securities from available information, with a particular focus on accounting information”. ${ }^{2}$ Residual income model is conceptually equivalent to the dividend discount model. The Ohlson model
adds the linear information dynamics.
} 
We hypothesize that 1) there are some bank-specific, industrial-specific and macroeconomic variables with explanatory power on the abnormal profitability of banks; and, if this is so, 2) those variables are useful to make forecasts on future abnormal profitability.

Using bank-level and country-level data, we apply a correlation analysis and different types of regression, the latter grouped into two estimation techniques: Ordinary Least Squares and Generalized Least Squares random-effects panel data analysis.

As for the first hypothesis, our results indicate that, for the whole sample, several variables are significant, being the signs of the coefficients, in general, consistent with economical reasoning and evidence found in previous studies. Loan Loss Provision Ratio, Fee Income Ratio, Overheads Ratio, Market Share of Loans, Economic Freedom, Index of Accepted Applications, State Ownership, Average Size of Banks in the Country, and Accounting Conservatism appear as the abnormal profitability determinants.

Our model explanatory power improves when we test a non-lineal relation with the accounting conservatism variable.

With regard to our second hypothesis, we test it over one-year forecast horizon, by regressing the dependent variable on an increasing pool of independent variables. In this way, making several regressions, we can analyze the incremental effect of one or two factors in addition to the previously analyzed variables.

The result points to the relevant role of some of those variables in explaining the future abnormal profitability: Fee Income Ratio, at the firm level; Market Share of Loans, Average Size of Banks in the Country, Index of Accepted Applications, State Ownership, at the industry level; and Accounting Conservatism, at the macroeconomic level. It can be clearly appreciated the incremental value added by the industrial and macroeconomic variables on the firm level one. In sum, the first five variables let us to interpret that banks operating in more competitive environments might outperform the expectations and, thus, generate abnormal ROEs. The last variable suggest that, besides, when banks release information in accounting conservative countries, the accounting system probably hides some relevant information, making abnormal earnings more frequent.

The work is structured as follows: Section 2 provides a review of related literature both in the determinants of abnormal profitability in the financial sector, as well as on the general profitability determinants within the banking industry. Section 3 develops hypotheses about the abnormal profitability determinants and proposes the model. Section 4 describes the data set. Section 5 reports our findings about the association of the independent variables with abnormal profitability in banking industry, the explanatory and the prediction power of the model. Section 6 presents the conclusions. 


\section{Literature review}

There are several related strands of literature. Some findings of the growing literature on the determinants of abnormal income or profitability are highlighted, especially in the financial sector. The empirical literature that has investigated the relationships between bank-specific and structural factors and performance in the banking industry are also reviewed.

\subsection{Determinants of abnormal profitability}

We have found several empirical papers in which financial firms are evaluated in relation to some aspects of the residual income model, or its more elaborated version: the Ohlson Model.

A first group of works applies residual income valuation techniques to financial firms for valuation purposes. This is the case of Danbolt and Rees [2002] or Begley et al. [2003].

A second group of studies examines the impact of certain bank-specific factors on equity valuation in the context of abnormal earnings and residual income model. Bank intangible assets are the certain variables in which Kohlbeck et al. [2002] and Kohlbeck [2004] are interested.

A more useful group is made up by papers that investigate the determinants of current or future residual income for firms operating in certain industries, even though not in the financial one. Our main references for the present work are Cheng [2005], and Bowen et al. [2002].

Danbolt and Rees [2002] extend the recent literature concerning accounting based valuation models to investigate financial firms from six European countries with substantial financial sectors: France, Germany, Italy, Netherlands, Switzerland and the UK. In most countries they find that the valuation models work as well, or better, in explaining cross-sectional variations in the market-to-book ratio for financial firms as they do for industrial and commercial firms in the same countries, although Switzerland is an exception to this generalization. The results are sensitive to industrial differences, accounting regulations and accounting practices. In particular, marking assets to market value reduces the relevance of earnings figures and increases that of equity.

Begley et al. [2003] use the residual income valuation technique outlined in Feltham and Ohlson [1996] to examine the relation between market value and accounting numbers for a prototypical banking firm. Key elements of their model include allowing banks to generate positive net present value from lending and/or borrowing activities, and, allowing for accounting policy to affect valuation through the loan loss allowance. The model highlights why bank valuations are likely to be balance sheet oriented. Their results suggest that banks create more value from deposit-taking activities than from loan-making activities. A surprising additional finding is that loan loss reserves seem to 
be based on aggregate loan levels rather than based on specific identification of bad loans.

Kohlbeck and Warfield [2002] hypothesize that the level of unrecorded intangible assets affects the implementation of the RIM and they document a significant and positive association between levels of bank unrecorded intangible assets and abnormal earnings. They also find that the pricing multiples for abnormal earnings increase from lower to higher levels of unrecorded intangible assets. Subsequent tests on the components of abnormal earnings and on adjusted book value and abnormal earnings corroborate the earlier findings of a relationship between abnormal earnings and unrecorded intangible assets.

Kohlbeck [2004] examines the value relevance and reliability of bank intangible asset measures. He estimates four customer-based intangible assets: the core deposit intangible, mortgage servicing rights, credit card intangible, and trust operations intangible, using publicly available information. Incorporating detailed financial and market information he finds his estimates are value-relevant. The improvement is driven by estimates of the two intangible assets, where recorded amounts are not separately reported: the core deposit and trust operations intangible assets. Evidence obtained suggests that his estimates are more reliable than balance sheet amounts. However, additional assumptions necessary to define the estimates add noise and partially account for observed lower reliability of his mortgage servicing rights estimate compared to that based on a simple algorithm.

Cheng [2005] investigates the determinants of residual income scaled by book value of equity, i.e., abnormal return on equity (ROE), by analyzing the impact of value-creation (economic rents) and value-recording (conservative accounting) processes on abnormal ROE. He relies on economic theories to characterize economic rents and develop an empirical measure - the conservative accounting factor - to capture the effect of conservative accounting. As expected, industry abnormal ROE increases with industry concentration, industry level barriers to entry, and industry conservative accounting factors. Also, as expected, the difference between firm and industry abnormal ROE increases with market share, firm size, firm level barriers to entry, and firm conservative accounting factors. Integrating these determinants into the residual income valuation model significantly increases its explanatory power for the variation in the market-tobook ratio.

Bowen and Shores [2002] investigate the determinants of the present value of future residual income for firms operating in the pharmaceutical industry. As residual income has both economic and accounting components, they exploit the industrial organization and competitive strategy literature to identify general features of economic context that are likely to be related to the generation of economic profit. Applying this framework to the pharmaceutical industry, they identify four determinants of the economic component of residual income and select ten accounting variables to proxy for these determinants. Then they draw on prior accounting research to specify when they expect accounting rules to create period-by-period timing differences between economic profit and residual income. In the pharmaceutical industry, research and development and advertising are important activities and the accounting rules for these items are likely to systematically bias residual income relative to economic profit. The authors combine their analysis of economic and accounting determinants of residual income to develop 
industry-wide hypotheses relating the ten accounting variables to the prediction of the present value of future residual income. The results of the empirical analyses are generally consistent with these hypotheses and the explanatory power of the model is quite high.

Overall previous literature in this section suggests the relevance of aspects such as industrial differences (concentration, barriers to entry) accounting regulation and practices (conservative accounting), operative performance (lending and borrowing activities), discretionary accounting items (loan loss allowances), and other unrecorded items (intangible assets ${ }^{3}$ ).

\subsection{Determinants of performance in the Banking Industry}

The behavior of the banks is the result of a wide variety of constraints, rules, and legal structures that underlie the market. These legal rules determine the incentives, strategies, and gains and losses of participants, which in turn determine the behavior the market exhibits. Viewed at this ground level, the behavior of markets is a complex process that is crucially dependent on these legal rules and structures.

In the early 1990s, the empirical banking research on the effects of bank concentration and competition ${ }^{4}$ most often tested whether the traditional structure-conductperformance (SCP) hypothesis ${ }^{5}$ applied to the U.S. banking industry. Now, the research has generalized beyond SCP hypothesis, and authors have specified alternative measures of competitiveness, including indicators of market structure that allow for the possibility that different sizes and types of commercial banks may affect competitive conditions differently. The measures of conduct and performance that are analyzed have expanded to include indicators of the efficiency, service quality, and risk of the banks, as well as consequences for the economy as a whole. More dynamic analyses of bank competition have been added, examining the effects over time of bank consolidation. Research has also broadened the focus from local U.S. Banking to other nations around the world.

The traditional banking business of accepting deposits and making loans has declined significantly in the US in last years [Allen and Santomero, 2001]. This trend can be observed in other countries too. The US and UK appear most similar, with France and Japan moving toward the Anglo-Saxon model, and Germany still quite different.

This situation seems to have been produced by the significant changes that have taken place in the financial system in recent decades. As markets become more competitive, banks are forced to look for new income sources, moving away from simple balance intermediation toward fee-producing activities. Thus, after examining the changes in the sector and their effects on the European banks income structure, ECB [2000] finds that

\footnotetext{
${ }^{3}$ Banks typically enjoy nontrivial benefits from reputation, monopoly rents, economies of scale and superior information in the financial markets. The banking literature calls these benefits the charter value or monopoly rents.

${ }^{4}$ See Berger and Hannan [1989], Hannan [1991], Neumark and Sharpe [1992].

${ }^{5}$ The SCP hypothesis argues that bank concentration and other impediments to competition create an environment that affects bank conduct and performance in unfavourable ways from a social viewpoint.
} 
disintermediation is a fact ${ }^{6}$. European banks have been losing their relative share of financial intermediation to institutional investors (investment funds, insurance companies and pension funds). In this situation, banks have reacted by including those institutional investors within large banking groups, to get additional sources of income. The effects of these responses are mainly reflected in changes in the structure of bank income and, in particular, in the increasing incidence of non-interest income. They are also reflected in the increasing size of off-balance-sheet items in the banks' financial accounts.

The main findings of the ECB [2000] survey on no-interest income can be summarized as follows:

1. The composition of non-interest income is rather heterogeneous.

2. Non-interest income has been the most dynamic component in the bank income structure in recent years.

3. The increase in non-interest income seems to have had a positive effect on bank's profitability in recent years.

4. In several EU countries an inverse correlation between interest and non-interest income seems to exist, although in a varying degree.

5. Non-interest income as a whole does not seem to be less volatile than interest income.

However, improved profitability has also been the result of other factors such us better cost control and more efficient use of banks' capital. Therefore, the relationship between profitability and activities generating non-interest income is not straightforward.

From another point of view, large banks and financial groups seem to get a competitive advantage in developing many non-interest income-generating activities. Moreover, large institutions are probable more able to attract and retain the highly qualified personnel needed to develop new and more sophisticated products. But small banks may have a comparative advantage over large banks within specific environments ${ }^{7}$. Some of the recent research on the effects of bank competition allows for the possibility that the size of banks may affect competitive conditions differently. Small banks are often considered to be "community banks" with different competitive advantages from those offered by large banks. As compared to larger banks, small banks in developed countries tend to serve smaller, more local customers, and to provide more retailoriented rather than wholesale-oriented financial services [DeYoung et al., 2004].

Likewise, different size banks may deliver their services using different technologies. The literature shows that large banks tend to make hard-information-based transaction

\footnotetext{
${ }^{6}$ In another research, Schmidt et al. [1999] present an empirical analysis of the alleged transformation of the financial systems in the three major European economies, France, Germany, and the United Kingdom. They find that there is neither a general trend toward disintermediation, nor toward a transformation from bank-based to capital market-based financial systems, nor toward a loss of importance of banks. Only in the case of France could strong signs of transformation as well as signs of a general decline in the role of banks be found. Thus, the three financial systems do not seem to be converging. However, there is a common pattern of change: the intermediation chains are lengthening in all three countries. Nonbank financial intermediaries are taking over a more important role as mobilizers of capital from the nonfinancial sectors. In combination with the trend toward securitization of bank liabilities, this change increases the funding costs of banks and may put banks under pressure. In the case of France, this change is so pronounced that it might even threaten the stability of the financial system.

${ }^{7}$ See Calem [1994], Nakamura [1994], Brickley et al. [2003].
} 
loans to larger, safer, more transparent borrowers, while small banks tend to make more soft-information-based relationship loans to smaller, riskier, more opaque borrowers [Berger et al., 2002].

But as a core element within the monetary policy, the banking industry is strongly regulated. Modern banking regulations in most countries rests on three pillars: prudential supervision with capital adequacy rules, deposit insurance with bailout or crisis management and a regulatory framework that sets the rules for competition among banks.

If we consider regulation under a different perspective, in common law countries, managers and boards have more flexibility than they do in civil law countries. The research has shown that indicators of creditor and shareholder rights, banking and financial regulations, openness of trade and entry, and so forth have important effects on competition among banks and between banks and financial markets, with significant consequences for economic growth (e.g. La Porta et al. [1997; 1998]).

Competition is generally viewed as being desirable because it leads to efficiency but is complicated by the necessity of maintaining financial stability. Greater competition may be good for efficiency, but bad for financial stability. Allen and Gale [2004] use a variety of models to address this question and find that different models provide different answers. The relationship between competition and stability is complex (sometimes competition increases stability). In addition, in a second-best world, concentration may be socially preferable to perfect competition and perfect stability may be socially undesirable.

According to Allen and Gale [2004] "Technological innovation is one of the major sources of growth in welfare. As Schumpeter famously pointed out, perfect competition undermines the incentive to innovate (when intellectual property rights are weak) and in that sense imperfect competition may be more "efficient" than perfect competition. Similar ideas apply in the financial sector. If banks innovate they may be able to capture the market and drive other banks out of business. Thus Schumpeterian competition may be associated with financial instability (creative destruction).”

Stulz and Williamson [2003] explore whether differences in culture should be taken seriously as a possible explanation for differences in investor protection. Differences in culture, proxied by differences in religion and language, cannot be ignored when examining why investor protection differs across countries. They show that a country's principal religion predicts the cross-sectional variation in creditor rights better than a country's natural openness to international trade, its language, its income per capita, or the origin of its legal system. Catholic countries protect the rights of creditors less than Protestant countries. A country's natural openness to international trade mitigates the influence of religion on creditor rights. Culture proxies are also helpful in understanding how investor rights are enforced across countries.

Demirgüç-Kunt et al. [2004] examine the impact of bank regulations, market structure, and national institutions on bank net interest margins and overhead costs using data on over 1,400 banks across 72 countries while controlling for bank-specific characteristics. The data indicate that tighter regulations on bank entry and bank activities boost the cost of financial intermediation. Inflation also exerts a robust, positive impact on bank 
margins and overhead costs. While concentration is positively associated with net interest margins, this relationship breaks down when controlling for regulatory impediments to competition and inflation. Furthermore, bank regulations become insignificant when controlling for national indicators of economic freedom or property rights protection, while these institutional indicators robustly explain cross-bank net interest margins and overhead expenditures. Thus, bank regulations cannot be viewed in isolation; they reflect broad, national approaches to private property and competition.

Using bank-level data, Claessens and Laeven [2004] estimate the extent to which changes in input prices are reflected in revenues earned by specific banks in 50 countries' banking systems. They then relate this competitiveness measure to indicators of countries' banking system structures and regulatory regimes. The authors find systems with greater foreign bank entry and fewer entry and activity restrictions to be more competitive. They find no evidence that the competitiveness measure negatively relates to banking system concentration. Their findings confirm that contestability determines effective competition, especially by allowing (foreign) bank entry and reducing activity restrictions on banks.

Goddard et al. [2004] investigate the profitability of European banks during the 1990s using cross-sectional, pooled cross-sectional time-series and dynamic panel models. Models for the determinants of profitability incorporate size, diversification, risk and ownership type, as well as dynamic effects. Despite intensifying competition there is significant persistence of abnormal profit from year to year. The evidence for any consistent or systematic size-profitability relationship is relatively weak. The relationship between the importance of off-balance-sheet business in a bank's portfolio and profitability is positive for the UK, but either neutral or negative elsewhere. The relationship between the capital-assets ratio and profitability is positive. The growth regressions reveal little or no evidence of mean-reversion in bank sizes. Profit is an important prerequisite for future growth. Banks that maintain a high capital-assets ratio tend to grow slowly, and growth is linked to macroeconomic conditions. Otherwise, there are few systematic influences on bank growth. The persistence of profit appears higher for savings and co-operative banks than for commercial banks. Banks that maintain high capital assets or liquidity ratios tend to record relatively low profitability. There is some evidence of a positive association between concentration and profitability, but little evidence of a link between bank-level $\mathrm{x}$-inefficiency and profitability.

Wilson and Williams [2000] investigate the relationship between size and growth for a sample of banks in France, Germany, Italy and the UK over the period 1990 to 1996. Using several measures of bank size (total assets, equity and value of off-balance sheet business), they test for size effects on growth, using models which incorporate the influences of previous growth, bank type and country of origin. The results of the analysis suggest that for Italy, small banks tend to grow faster than larger banks. No relationship is found between bank size and growth for France, Germany and the UK. This suggests a process of increasing concentration in these banking systems, even in the absence of bank-specific strategic advantages. Small banks tend to have more variable growth rates than their larger counterparts. This suggests that large banks may enjoy advantages associated with diversified operations, which make them less susceptible to periods of extremely high or low growth. 
Atanasoglou et al. [2005] examine the effect of bank-specific, industry-specific and macroeconomic determinants of profitability on Greek banking sector, over the period 1985-2001. The estimation results show that profitability persists to a moderate extent, indicating that departures from perfectly competitive market structures may not be that large. All bank-specific determinants, with the exception of size, affect bank profitability significantly in the anticipated way: capital, credit risk, labor productivity, growth, and expenses management. Both industry-specific variables (ownership status, and concentration) seem to be insignificant in explaining profitability. No evidence is found in support of the traditional Structure-Conduct-Performance (SCP) hypothesis. Finally, the business cycle has a positive, albeit asymmetric effect on bank profitability, being significant only in the upper phase of the cycle.

Overall, previous literature gathered in this section suggests the relevance of aspects such as management (better cost control, more efficient use of capital, credit risk, labor productivity), diversification (non-interest income), banking regulation (creditor and shareholder rights, investor protection, financial rules, openness of trade and entry), market structure (competition, concentration, business cycle) and bank-specific structure (size, ownership type).

\section{An Industry Approach: Empirical Model}

This section outlines the theoretical and empirical methodology used for modeling abnormal profitability in OECD banking. After a brief specification of what abnormal profitability means, we propose the general model to be estimated, and list the independent variables used. Previous empirical studies and economical reasoning serve us to form hypotheses about the behavior of these variables within the model.

\subsection{Abnormal ROE}

The concept of "abnormal ROE” is very similar to the well-known ROE (earnings, X, divided by previous year book value of equity, B).

$$
R O E=\frac{X_{t}}{B_{t-1}}
$$

If we use Abnormal Earnings, as computed by Ohlson, instead of the reported earnings, we get Abnormal ROE:

$$
R O E_{t}^{a} \equiv R O E_{t}-r=\frac{X_{t}}{B_{t-1}}-r=\frac{X_{t}-r B_{t-1}}{B_{t-1}} \equiv \frac{X_{t}^{a}}{B_{t-1}}
$$

Therefore, Abnormal ROE is the difference between ROE and the firm's cost of equity.

$$
R O E_{t}^{a} \equiv R O E-r
$$

To compute the Cost of Equity we use CAPM ${ }^{8}$

${ }^{8} r=r_{\text {free }}+\beta\left(\tilde{r}-\tilde{r}_{\text {free }}\right)$; Risk Premium: 4.5\%; Beta: Country Average of One-Year Beta Reported by Bankscope; Interest Rate: Long Term Interest Rate in the country. 


\subsection{Variables}

We hypothesize that Abnormal ROE is the result of a number of factors. We can divide them into three groups: firm level, industry level and macroeconomic level.

$$
R O E_{t, i}^{a}=f\left(\text { FIRM }_{m}, \text { INDUSTRY }_{l}, \text { MACRO }_{l}\right)
$$

Previous revision of banking and accounting literature shows that at a firm level, the key proxies of value drivers are: Loan Loss Provision (LLLP), Size (SIZE), Bank Equity (or Leverage, LEV), Liquidity of Assets (LIQ), Management Efficiency (MGE), Fee Income (FEE), and Overheads (OVER).

$$
R O E_{t, i}^{a}=f\left(L L L P_{i}, S_{Z Z E_{i}}, L E V_{i}, L I Q_{i}, M G E_{i}, F E E_{i}, O_{V E R} ; I_{N D U S T R Y_{l}} ; M_{A C R O}\right)
$$

Loan Loss Provision Ratio (LLLP) equals the loan loss provision divided by total loans of the bank. In a first view, an increase of provisions reflects that probably more loans will turn out to be unpaid, that is, more provisions mean a worse situation in expected future loan collection. But prior research suggests three motives for bank managers' discretionary behavior with respect to loan loss provisions: income smoothing, signaling and capital management. Several empirical studies obtain evidence consistent with a positive relation between stock returns and loan loss provisions (Beaver et al. [1989], Elliot et al. [1991], Griffin and Wallach [1991], Wahlen [1994]). These papers conjecture that perhaps the market interprets provisions as revelations of bank managers' private information about expected future earnings. Consequently with the general reasoning, we expect a negative sign for the relation:

$$
\uparrow L L L P \Rightarrow \uparrow \text { Future bad loans } \Rightarrow \downarrow \text { AROE }_{\mathrm{t}}
$$

Size (SIZE) equals the logarithm of total bank assets. Size may be an important determinant of net interest margins if there are increasing returns to scale in banking. (Demirgüç-Kunt et al., 2004: 603). If larger banks have lower average costs, then profits will be a convex function of the size of the bank (Allen and Gale, 2004, p. 467). The explanations proposed by previous studies may be economies of scale or scope, efficiency gains, the adoption of entry-deterring strategies, or the exercise of other forms of market power (Goddard et al. 2004: 1069). Results obtained by Wilson and Williams (2000: 1101) suggest that large banks may enjoy advantages associated with diversified operations, which make them less susceptible to periods of extremely high or low growth. All these advantages lead us to predict a positive sign for the relation with abnormal ROE.

$$
\uparrow \mathrm{SIZE} \Rightarrow \uparrow \text { Size - related Advantages } \Rightarrow \uparrow \mathrm{AROE}_{\mathrm{t}}
$$

Leverage Ratio (LEV) equals the book value of debts divided by total assets. Financial theory justifies that a firm's average cost of capital reduces as leverage rises, at least until the firm gets a level of risk in which leverage-induced reduction equals riskinduced increase. In addition to this general reasoning, some theories suggest that wellcapitalized banks face lower funding costs due to lower expected bankruptcy costs (Demirgüç-Kunt et al. 2004: 603). But, in our opinion, this is not evidence against; in fact, it supports the general idea of a non-lineal increase of costs when risk (of bankruptcy in this case) reaches a critical level. Thus, assuming that loan rates do not 
vary much with bank leverage, higher bank leverage ratios would imply larger net income, what would be translated in a higher abnormal ROE.

$$
\uparrow L E V \Rightarrow \uparrow \text { Net income } \Rightarrow \uparrow A R O E_{\mathrm{t}}
$$

Liquidity of Assets (LIQ) equals the liquid assets of the bank divided by total assets. As banks with high levels of liquid assets in cash and government securities may receive lower interest income than banks with less liquid assets (Demirgüç-Kunt et al. 2004: 603), we can suppose that greater liquidity will tend to be negatively associated with interest margins, and with abnormal ROE. To work properly, this indicator requires a competitive market for deposits.

$$
\uparrow L I Q \Rightarrow \downarrow \text { Interest income } \Rightarrow \downarrow \text { AROE }_{\mathrm{t}}
$$

Management Efficiency (MGE) equals total earning assets divided by total assets. Since efficient management makes possible more profits with the same resources, we take bank assets as a proxy of those resources. This way, a higher proportion of earning assets would be a sign of efficiency while a higher proportion of fixed and non-earning assets would indicate inefficiency. Earning assets include loans, deposits with banks, securities, and equity investments. More relevant non-earning assets include cash, notremunerated deposits, intangible fixed assets and accrual accounts.

$$
\uparrow M G E \Rightarrow \uparrow \text { Net Income } \Rightarrow \uparrow A_{\mathrm{ROE}}
$$

Fee Income (FEE) equals non-interest-operating income divided by total assets. An increase in gains of a bank will make the positive balance of the gains and losses account higher. But banks have different product mixes. These differences may influence the pricing of loan products. A reasonable explanation argues that welldeveloped fee income sources will produce lower interest margins due to crosssubsidization of bank activities (Demirgüç-Kunt et al. 2004: 603). According to the better bargaining power of banks in relation to their clients, we estimate a positive net relation with abnormal ROE.

$$
\uparrow \mathrm{FEE} \Rightarrow \uparrow \text { Net Income } \Rightarrow \uparrow \mathrm{AROE}_{\mathrm{t}}
$$

Overhead Ratio (OVER) equals overhead costs divided by total assets. This variable may be used as a measurement of bank efficiency /performance as it can capture crossbank differences in organization and operation. Different business systems, product mixes, and asset allocations mean different overhead cost structures. Consequently, cost inefficiencies or low levels of market competition may be reflected in high overhead costs (Demirgüç-Kunt et al. 2004: 603). This way, a higher overhead ratio would mean a lower abnormal ROE.

$$
\uparrow \mathrm{OVER} \Rightarrow \downarrow \text { Efficiency / Market competition } \Rightarrow \downarrow \text { AROE }_{\mathrm{t}}
$$

The business environment of the firm consists of all the external influences that affect its decisions and performance. In practice, there are many features of an industry that determine the intensity of competition and the level of profitability. A helpful, widely used framework for classifying and analyzing these factors is the one developed by 
Michael Porter. Porter, in his Five Forces of Competition framework, views the profitability of an industry (as indicated by its rate of return on capital relative to its cost of capital) as determined by five sources of competitive pressure. These five forces of competition include three sources of "horizontal" competition: competition from substitutes, competition from entrants, and competition from established rivals; and two sources of "vertical" competition: the bargaining power of suppliers and buyers.

In spite of the fact that the strength of each of these competitive forces is determined by a number of key structural variables, we proxy these forces in the following way:

* Substitutes: The existence of close substitutes means that customers will switch to substitutes in response to price increases of the product. The extent to which substitutes limit prices and profits depends on the propensity of buyers to substitute between alternatives. To avoid substitution, banks tend to use the strategy of cross-selling, offering simultaneously different products, such as deposits, loans, mortgages, or credit cards. Hence, it is likely that banks with a higher Market Share of Loans have a higher number of linked clients, hardly inclined to change. Market Share of Loans (MSL) equals the bank's loans divided by total commercial bank loans in the country. So, we predict a positive sign for the relation with abnormal ROE.

$$
\uparrow M S L \Rightarrow \downarrow \text { propensity to substitute } \Rightarrow \uparrow A R O E_{\mathrm{t}}
$$

* Threat of Entry: New entrants cannot enter on equal terms with those of established firms. The size of the advantage of established over entrant firms (in terms of unit costs) measures the height of barriers to entry, which determines the extent to which the industry can, in the long run, enjoy profit above the competitive level. We use the Average size of banks in the country (AS) as a proxy to measure this factor, and we expect a positive sign for the relation with abnormal ROE.

$$
\uparrow A S \Rightarrow \uparrow \text { Barriers to entry } \Rightarrow \uparrow A R O E_{\mathrm{t}}
$$

* Rivalry between Established Competitors: We proxy the intensity of competition with the Index of Applications Accepted for Domestic Commercial Banks Licenses (IA) which equals one minus the fraction of entry applications denied. Taking that more licenses imply increasing rivalry, the relation with abnormal ROE should be negative.

$$
\uparrow I A \Rightarrow \uparrow \text { Rivalry } \Rightarrow \downarrow A R O E_{\mathrm{t}}
$$

* Bargaining Power of Customers: The strength of buying power that firms face from their customers depends on their relative bargaining power. We use the Economic Freedom Index of the Heritage Foundation as a proxy (EF). This is an overall indicator that ranges from 1 to 5 (more freedom for larger values) (Demirgüç-Kunt et al. 2004: 603) to measure the extent to which individuals and firms feel free to conduct their businesses. Assuming more customer power when freedom is wider, we predict a negative relation with abnormal ROE.

$$
\uparrow E F \Rightarrow \uparrow \text { Customer Power } \Rightarrow \downarrow \text { AROE }_{\mathrm{t}}
$$


* Bargaining Power of Suppliers: Generally, the key issues are the ease with which the firms in the industry can switch between different input suppliers and the relative bargaining power of each party. But Commercial Banks depend on institutional factors. We proxy this factor with two variables: 1) State Ownership (SO) which measures government involvement in the banking industry; and 2) Activity Restrictions (AR) that indicates the degree to which banks face regulatory restrictions on their activities in securities markets, insurance, real-estate, and owning shares in non-financial firms. State ownership equals the share of banking system assets that are in state-owned banks, where state-owned is defined as $50 \%$ or more state ownership. As banking systems dominated by state-banks tend to be inefficient and less open to entry (Demirgüç-Kunt et al. 2004: 605), this barrier would imply a negative relation with abnormal ROE. Regarding the second variable, Activity Restrictions, our prediction is that they mean limitations for bank activities, and hence a negative relation with abnormal ROE.

$$
\begin{gathered}
\uparrow S O \Rightarrow \uparrow \text { government involvement in the banking industry } \Rightarrow \downarrow A \mathrm{ROE}_{\mathrm{t}} \\
\uparrow A C T R \Rightarrow \uparrow \text { regulatory restrictions on bank activities } \Rightarrow \downarrow A \mathrm{ROE}_{\mathrm{t}}
\end{gathered}
$$

Additionally, we have considered two macroeconomic variables: the Accounting conservatism (AC) and the Annual Change of Long Term Interest Rate (DLTIR). We include both of them at industry level, as they are constant for all the banks in a country.

Accounting Conservatism (AC) equals one for those countries with a less conservative accounting system (USA, UK, and countries following International Standards); and equals zero in other countries. A variety of definitions for conservative accounting have been given. FASB (1980: 2) defines conservatism as "a prudent reaction to uncertainty to try to ensure that uncertainty and risks inherent in business situations are adequately considered”. Researchers use three types of measures to assess conservatism:

* net asset measures,

* earnings and accrual measures, and

* earnings/stock returns relation measures.

All measures rely on the effect of conservatism's asymmetric recognition of gains and losses on reported accounting numbers, in particular net assets, earnings, and accruals. Some such as Basu [1997] define conservatism as the practice of reducing earnings (and writing down net assets) in response to "bad news", but not increasing earnings (and writing up net assets) in response to "good news". In a similar sense, Watts (2003: 208) adopts a "differential verification" interpretation when considering that conservatism is the asymmetrical verification requirement for gains and losses (the greater the difference in degree of verification required for gains versus losses, the greater the conservatism). It is well known the Feltham and Ohlson [1995] characterization of conservative or "biased" accounting as an expectation that reported net assets will be less than market value in the long run. That definition classifies the accounting for anticipated positive net present-value investments at historical cost as conservative accounting, because the analyst expects those investments to be carried at less than their value. Zhang [2000] models conservative accounting and valuation from this perspective. Beaver and Ryan [2000] similarly characterize conservatism (or bias) as a persistent difference between market value and book value that is distinct from temporary differences due to economic gains and losses that are recognized in book value gradually over time. Gjesdal (1999) distinguishes "economic profitability" from 
accounting profitability. He characterizes accounting as conservative if it assigns investments a carrying value that yields an expected accounting rate of return greater than the internal rate of return on their cost.

As for the alternative explanations for conservatism, Watts (2003: 207) finds contracting, shareholder litigation, taxation, and accounting regulation, even though the evidence suggests that the contracting and shareholder litigation explanations are the most important.

To quantify the impact of conservative accounting on abnormal ROE, we start from the Penman and Zhang [2002] and Cheng [2005] findings. Expensing an investment with future benefits has a negative impact on abnormal ROE in the investment period, and a positive impact for the rest of its useful life. If the growth of investments is high, the negative impact dominates, while if the growth is low, the positive impact dominates.

$$
\begin{aligned}
& A C=1 \text { AND High growth } \Rightarrow \downarrow \text { AROE }_{\mathrm{t}} \\
& A C=1 \text { AND Low growth } \Rightarrow \uparrow \text { AROE }_{\mathrm{t}}
\end{aligned}
$$

Change in Long Term Interest Rates (DLTIR) equals long-term interest rate at period t minus long-term interest rate at the previous period, $t-1$. In banks, changes in interest rates produce changes in other assets and liabilities. For instance, Ahmed and Takeda (1995: 225) argue that changes in interest rates have a significant negative effect on bank stock returns. Beaver et al. (1989: 177) try to explain variation in banks' marketto-book ratios. In this process, they also find that the magnitudes of the coefficients on the maturity variable vary with changes in nominal interest rates. In commercial banks, the balance for interest-bearing assets and liabilities should be positive, so that we predict a positive relation to abnormal earnings when interest rates are higher and a negative relation when interest rates are lower, even though there is no possibility to transfer the whole changes immediately to the clients.

$$
\begin{aligned}
& D L T I R>0 \Rightarrow \uparrow \text { AROE }_{\mathrm{t}} \\
& D L T I R<0 \Rightarrow \downarrow \text { AROE }_{\mathrm{t}}
\end{aligned}
$$

The resulting function permits us to assess the impact of bank-specific characteristics and the macroeconomic and industrial environment.

$$
\begin{aligned}
& A R O E_{i t}=f\left(L L L P_{i}, S I Z E_{i}, L E V_{i}, L I Q_{i}, M G E_{i}, F E E_{i}, O V E R_{i}, A C, D L T I R, M S L, A S, I A, E F, S O, A C T R\right) \\
& A R O E_{i t}=f(\overbrace{L L L P_{i}, S I Z E_{i}, L E V_{i}, L I Q_{i}, M G E_{i}, F E E_{i}, O V E R}^{\text {Firm Level }}, \overbrace{A C, D L T I R, M S L, A S, I A, E F, S O, A C T R}^{\text {Industry \& Macro Level }})
\end{aligned}
$$

According to this, we contrast the following econometric model with $i$ Banks in $j$ countries and $t$ years:

$$
A R O E_{i t}=\alpha_{i t}+\sum_{i=1}^{z} \beta_{i t} \text { Firm }_{i t}+\sum_{j=1}^{k} \gamma_{j t} \text { Industry }_{j t}+\sum_{j=1}^{k} \lambda_{j t} \text { Macro }_{j t}+\varepsilon_{i t}
$$




\section{Data}

The initial sample includes all commercial banks in the OECD countries covered by the Bankscope database over the period 1997-2003. We use data from consolidated accounts, if available, and otherwise form unconsolidated accounts (to avoid doublecounting). Observations with lagged data are needed to calculate book value-adjusted ratios (i.e. ROE). Information on commercial bank licenses, state ownership, types of activity, is obtained from the World Bank Survey of Bank Regulation and Supervision database. The Economic Freedom Index comes from the Heritage Foundation. To reduce the effects of extreme observations we delete the $2.5 \%$ extreme values of the dependent variable. Table 1 reports description and source of the variables used.

Table 2 presents the sample composition (3,287 bank-year observations). The table is divided into two panels: Panel A shows the summary statistics of Abnormal ROE (AROE) by year, with a minimum of 335 observations in 1997 and a maximum of 632 observations in 2003. Panel B shows the summary statistics of AROE by country (Range: from 11 observations in Island to 566 observations in Japan).

Table 3 contains descriptive statistics for all the variables. Panel A shows descriptive statistics for abnormal ROE and bank-specific variables: LLLP, SIZE, LEV, MGE, LIQ, FEE, OVER and MSL. Abnormal ROE has a positive mean value close to zero, but it ranges from a low of -1.00 to 0.44 . (with strong dispersion) ${ }^{9}$. Besides, the sample includes banks with very different sizes and business mixes. Panel B shows descriptive statistics for the macroeconomic and financial environment variables: EF, IA, SO, ACTR, AS, DLTIR, and AC.

Economic freedom index ranges from 1.6 to 3.5 in the countries where the banks are established. Government interference in the banking system varies considerably from country to country and the same can be said about the size of the banking industry. As for the accounting conservatism variable, the sample gathers a similar number of banks in any of both groups: banks from a country with more conservative rules and banks from a country with less conservative rules.

\section{Empirical Results / Evidence}

Prior literature suggests that each of these factors has incremental explanatory power in determining stock returns after controlling for the other. The economic interpretation for the information content of the model can be divided into two categories:

1-. Explanatory power of the model. We use the regression of abnormal ROE on bankspecific, industrial and macroeconomic variables, all of them referred to year $t$.

2-. Predictive power of the model. We use the regression of abnormal ROE in year $t+1$ on explanatory variables in year $t$.

\footnotetext{
${ }^{9}$ Negative extreme values correspond to Turkey, where interest rates are extremely high, resulting in a cost of capital considerably higher than in other countries.
} 


\subsection{Correlation analysis}

The correlation analysis serves us to explain the relation between the independent variables and the abnormal ROE.

Table 4 reports the correlations between the variables. Many of the correlations are not statistically significant; out of 120 correlations 91 are significant at the $5 \%$ level. Very few of these significant correlations concern relationships among the independent variables. There are, for example, significant positive correlations between size and the measures of leverage ratio, market share of loans and average size of banks in the country; between fee income and overheads ratio; and between economic freedom and state ownership, that we will comment a bit later.

None of the independent variables presents a high correlation with respect to the abnormal ROE (dependent variable). Some of the correlations are not even significant (i.e. variables without *). But, in general, the sign of the coefficients agrees with predictions made from economical reasoning and evidence found in previous studies.

- Changes in interest rates (DLTIR): the positive correlation confirms that the variable increase produces a higher difference between profitability and cost of capital.

- Loan loss provision ratio (LLLP): the negative correlation (the higher the provisions, the lesser the abnormal profitability) means that provisions reveal the coverage of negative contingencies. This result does not support the evidence found by various authors in which the loan loss provision item works as a signal of good bank management of future losses. In our opinion, the relation between LLLP and AROE is directly affected by the certain risk exposure of the bank. When higher provision means higher risk, cost of capital increases and, hence abnormal ROE decreases. On the other hand, when higher provision does not mean higher risk, bank managers do so well that abnormal ROE may increase.

- Size (SIZE): the positive correlation confirms the general accepted idea that bigger banks obtain better results.

- Leverage ratio (LEV): the positive correlation confirms that a higher leverage helps to get better profitability.

- Liquidity of assets ratio (LIQ): the negative correlation supports the general accepted idea that liquid assets are not productive.

- Management Efficiency (MGE): the positive correlation confirms that better management takes the bank to greater profitability.

- Fee income (FEE): the positive correlation confirms the reasonable primary prediction: an increase of a positive income should produce better profitability. Even though cross-subsidization of bank activities compensates a part of that increase, there is another part of fee income that banks are obtaining from activities they were doing before, but in exchange of a lesser price or even for free. Our results indicate that this second part of fees is weighted stronger. The strong positive correlation between fee income and overheads ratio suggests that a part of the fees 
comes from another group of activities other than those loan-related, within the process of disintermediation, for which several "new" costs are incurred.

- Overheads ratio (OVER): the negative correlation confirms that a way to improve profitability is reducing this type of costs, which is generally considered a signal of efficiency.

- Market share of loans (MSL): the positive correlation confirms our prediction. Therefore, we infer that propensity of clients to change to other banks is less, and it means better profitability.

- Economic freedom index (EF): the negative correlation confirms our prediction. Therefore, when the index is higher, we infer that the bank clients' bargaining power is greater, and it results in lesser profitability. The correlation matrix shows a strong relation between Economic freedom and State ownership. It indicates that government intervention in banking industry by means of property rights is lesser in those countries with a higher level of economic freedom.

- State ownership (SO): confirming our prediction, the negative correlation indicates that the more bank shares owned by the government, the less opportunities the private owners have to act and obtain abnormal returns.

- Activity restrictions (ACTR): the negative correlation confirms our prediction. This variable indicates the grade to which commercial banks are allowed to participate in different activities. Thus, a higher index means that commercial banks face less legal restrictions, having more opportunities to obtain abnormal ROEs.

- Average size of banks in the country (AS): the positive correlation confirms our prediction. A big banking industry in a country is a barrier to the entrance of new banks. Therefore, the bigger the banking industry is in a country, the fewer possibilities for the existing banks to receive new competitors who would reduce competitive advantages and abnormal ROE.

\subsection{Regression analysis}

To examine Abnormal ROE value drivers, that is, the ability of the independent variables considered to explain the dependent one, we use regression analysis. We run our regression using ordinary least squares. Table 5 presents the cross-sectional regression results for the following equation:

$$
\begin{aligned}
& \operatorname{AROE}_{i t}=\alpha_{0}+\sum_{i=1}^{z} \beta_{i t} \text { Firm }_{i t}+\sum_{j=1}^{k} \gamma_{j t} \text { Industry }_{j t}+\sum_{j=1}^{k} \lambda_{j t} \text { Macro }_{j t}+\varepsilon_{i t} \\
& \text { Firm }_{i}=\left\{L L L P_{i t}, \operatorname{SIZE}_{i t}, L E V_{i t}, L I Q_{i t}, M G E_{i t}, \text { FEE }_{i t}, O_{\text {OVER }},\right\} \\
& \text { Industry }_{j}=\left\{M S L_{j t}, A S_{j t}, \operatorname{IA}_{j t}, E_{j t}, S O_{j t}, \text { ACTR }_{j t},\right\} \\
& \text { Macro }_{j}=\left\{\operatorname{DLTIR}_{j t}, A C_{j t}\right\}
\end{aligned}
$$


Most of the relationships have been found statistically significant, and the sign of coefficients supports the previously exposed economical reasoning in the case of: Loan Loss Provision Ratio (LLLP), Bank Size (SIZE), Liquidity of Bank Assets (LIQ), Fee Income Ratio (FEE), Overheads Ratio (OVER), Market Share of Loans (MSL), Economic Freedom (EF), Index of Accepted Applications (IA), State Ownership (SO), Index of Activity Restrictions (ACTR), Average Size of Banks in the Country (AS) and Accounting Conservatism (AC).

In this analysis, we perform Ordinary Least Squares regressions on a pool of data. To counter any heteroskedasticity ${ }^{10}$ effects $^{11}$, we have used Stata 9.1's "robust" regression (vid. robust t statistics in brackets).

As Table 5 shows, we make six regressions with different levels of aggregation. In this process, explanatory power clearly increases as significant variables add to make each new regression. If we only compute firm level variables, the explanatory power is very low (probably due to the wide heterogeneity of abnormal ROEs in the sample, with countries showing very different costs of capital). However, as we incorporate the contextual information through industry and macroeconomic approaches, the explanatory power considerably improves.

Resultant explanatory variables, that is to say, statistically significant variables are: LLLP, LIQ, FEE, OVER, MSL, EF, IA, SO, ACTR, AS and AC.

Considering previous accounting research, we take conservatism in accounting systems as the source of non-lineal relations. To incorporate this analysis in our study, we use a similar approach to that in Burgsthaler and Dichev (1997), running the following regression:

$$
\begin{aligned}
\text { AROE }_{i t}= & \alpha_{0}+\sum \beta_{i t} \text { Firm }_{i t}+\sum \gamma_{j t} \text { Industry }_{j t}+\sum \lambda_{j t} \text { Economy }_{j t}+ \\
& +A C \sum \beta_{i t}^{\prime} \text { Firm }_{i t}+A C \sum \gamma_{j t}^{\prime} \text { Industry }_{j t}+A C \sum \lambda_{j t}^{\prime} \text { Economy }_{j t}+\varepsilon_{i t}
\end{aligned}
$$

That is to say, regressions of Abnormal ROE (year t), with $i$ banks and $j$ countries. $\beta_{i t}$ represents a set of coefficients associated with firm level variables, $\gamma_{j t}$ industry level and $\lambda_{j t}$ economy level. Since AC takes values 0 or 1 , in countries with $\mathrm{AC}=0$ we will have $\left(\beta_{i t}, \gamma_{j t}, \lambda_{j t}\right)$, whereas when $\mathrm{AC}=1$, we will have:

$$
\left\{\left(\beta_{i t}+\beta_{i t}^{\prime}\right),\left(\gamma_{j t}+\gamma_{j t}^{\prime}\right),\left(\lambda_{j t}+\lambda_{j t}^{\prime}\right)\right\}
$$

\footnotetext{
${ }^{10}$ Breusch-Pagan / Cook-Weisberg test for heteroskedasticity and White Test suggests the presence of heteroskedasticity in the sample.

${ }^{11}$ Heteroskedasticity causes standard errors to be biased. OLS assumes that errors are independent and identically distributed; robust standard errors (Huber/White estimators or sandwich estimators of variance) relax that assumption. The use of robust standard errors does not change coefficient estimates, but (because the standard error are changed) the test statistics will give reasonably accurate p values. So, with the robust option, the point estimates of the coefficients are exactly the same as in ordinary OLS, but the standard errors take into account issues concerning heterogeneity and lack of normality.
} 
Table 6 depicts how explanatory power increases, up to a higher value than that obtained in Table 5, while some variables (OVER, AS, IA, SO, ACTR) seem to behave in a different manner depending on the accounting system followed in each country.

However, these regressions do not capture the joint effect of time-series and crosssectional information. The next section deals with this issue.

\subsection{Panel Data Analysis}

Up to this point, we have used OLS regressions. However, to take advantage of the richer information obtained by mixing cross-sectional and time-series data, we apply an appropriate econometric methodology for the estimation of panel data models.

A random-effects model is used because it includes a bank-specific random disturbance term that accounts for unexplained variation in the dependent variable that it is specific to each bank during the sample period.

For the whole analysis, the random-effects regression approach outperforms the OLS regression approach, applied on the same independent variables. It supports the idea that banks are different from each other but they keep some idiosyncratic features not captured by the independent variables yet, but present in a sort of persistence factor.

From our point of view, both hypotheses tested in the persistence of profit literature work at the same time for different banks, and at the same bank for different terms. The first one is that entry and exit are sufficiently free to eliminate any abnormal profit quickly, and that all firms' profit rates tend to converge to the same long-run average value (Goddard et al. 2004: 1070). The alternative is that some firms possess special knowledge or other advantages enabling them to prevent imitation or block entry. In these cases abnormal profit may tend to persist from year to year, and differences in average profit rates may be sustained indefinitely.

In Table 7, we use a panel data regression, in order to improve the analysis through the capture of both, cross-sectional and temporal relations. If we compare Tables 5 and 7 the result is a high level of significance for one variable (FEE), two no more significant variables (LIQ, ACTR), and very light changes in the rest (LLLP, OVER, MSL, AS, IA, $\mathrm{EF}, \mathrm{SO}, \mathrm{AC})$.

Until now, we have dealt with the contemporaneous relations among the variables, but our main concern is the prediction of future abnormal ROE. To do so, we regress the future abnormal ROE (dependent variable) on the same independent variables used before. The forecasts on future abnormal ROE referred to year $t+1$ are shown in Table 8. Other four regressions, not reported here, made for future abnormal ROE in years $t+2, t+3, t+4$ and $t+5$, let us confirm that the explanatory power reasonably decreases as forecasts refer to a longer period.

In Table 8, first column refers to the regression on bank-specific variables only. Fee Income is the unique statistically significant variable within this group, contributing positively to the following year's abnormal profitability. This way, the search for 
alternative income sources seems to be confirmed as a cause of better results than targeted by the market.

When introducing MSL (Market Share of Loans) and AS (Average Size of Banks) in a new regression, results for previous variables do not change, but the additional two are statistical significant, so that, FEE, MSL and AS contribute to the future abnormal profitability. As expected, next year's abnormal ROE increases when MSL is higher. But the contrary occurs with AS. Out of doubt, the established banks' size represents a barrier to new entrants, which helps the former to maintain their levels of profitability. Bigger size means a higher barrier and, consequently, better profitability, but our results suggest that the market can anticipate this positive effect, resulting in the lack of unexpected profitability. Furthermore, the negative sign indicates that abnormal ROE is possible if banks develop their business in a more competitive market.

The same idea might be considered behind the relation between abnormal ROE and IA (Index of Accepted Applications), when this variable adds to the previous ones in a new regression: new commercial bank licences increase competition. Anyway, this variable loose importance as more variables add to the pool.

The next significant variable is SO (Bargaining Power of Suppliers). As explained previously, the more government involvement in the banking industry, the less future abnormal ROE, via reductions in efficiency and market competitiveness.

Last column incorporates AC (Accounting Conservatism) as significant when all the variables proposed in this study are used in a regression. Banks from countries with accounting conservatism tend to obtain higher abnormal future ROE. This result is consistent with the general accepted idea that part of the 'other information' variable, in the Ohlson Model, appears due to the existence of accounting conservatism. The reasoning holds that accounting figures, when far from market values, cannot reflect the ability to produce more than the market.

As a conclusion of all mentioned about Table 8, we could say that banks' future abnormal profitability seems to be associated to some ways of increasing competitiveness and to the existence of accounting conservatism. As for the first reason, more competence pulls the banks to new income sources, making possible unexpected gains, and thus, abnormal ROE. As for the second, conservatism in accounting statements hides relevant information, such as intangibles or fair values, making possible again that banks outperform market expectations.

With a new regression of our prediction model, but taking again conservatism in accounting systems as a dichotomic variable, the same type of improvement has taken place (Table 9). That implies the existence of non-lineal relations between future abnormal ROE and the accounting system followed in each country. We do not reject that any other independent variable may relate with abnormal ROE in a non-lineal way. 


\section{Concluding Remarks and Further Research}

This study examines the effect of bank-specific, banking industry and macroeconomic determinants on the abnormal profitability for a large cross-section of countries. Previous studies of the banking industry deal with various aspects related to profitability, but our study adopts the value-creation point of view about the abnormal part of that profitability. In this sense, we have tried to identify some residual income determinants to contribute to a better value estimation within the framework of residual income models (i.e. Ohlson Model).

For a sample of banks from the OECD, over the period 1997-2003, we have tested the relation between abnormal profitability and three groups of variables: bank-specific, industry-specific and macroeconomic. Our dependent variable has a positive mean value close to zero with strong dispersion. The analysis of correlations between the variables shows that none of the independent variables presents a high explanatory power, even though, in general, the signs of the coefficients support economical reasoning and evidence found in previous studies.

Furthermore, OLS regressions show additional improvements in the explanatory power as we add contextual information to the firm level variables. Also, trying to improve the explanatory power of the model, we have tested a non-lineal relation with one of the independent variables: conservatism in accounting systems. This new regression indicates a better explanatory power while some variables seem to behave in a different manner depending on the accounting system followed in each country.

However, OLS techniques fails to capture the full extent of information related to time series and bank specific factors. To avoid this problem, we use a more sophisticated econometric technique (i.e. panel data analysis). After making the regression using a random-effects model, most of the relationships have been found statistically significant, and the sign of coefficients supports the previously exposed economical reasoning in the case of: Loan Loss Provision Ratio, Fee Income Ratio, Market Share of Loans, Economic Freedom, Index of Accepted Applications, State Ownership, Average Size of Banks in the Country, and Accounting Conservatism.

But our main interest is the relation between current variables and future abnormal ROE. Therefore, in order to test it, we regress following year's abnormal profitability on the same independent variables. Looking at the significant variables we interpret that banks' future abnormal profitability is associated to some ways of increasing competitiveness and to the existence of accounting conservatism. As for the first reason, more competence pulls the banks to new income sources, making possible unexpected gains, and thus, abnormal ROE. As for the second, conservatism in accounting statements hides relevant information, such as intangibles or fair values, making possible again that banks outperform market expectations.

The better working of the random-effects approach, supports the idea that banks keep some idiosyncratic features not captured by the selected independent variables. 
The main contribution of this study is the use of contextual analysis to examine the sources of abnormal profitability in banking industry. All the variables used have been selected starting from the economical reasoning or previous related studies. Among them, the independent variables selected by the regression process applied to our model seem to affect, directly and clearly, to the following year's profitability of banks from OECD countries. Thus, our work successfully applies the contextual approach to the identification of some components of the Ohlson Model's 'other information' variable in banking industry.

Throughout the work we have detect different types of difficulties: variables we have not information enough, proxies whose definition is not so direct as we would like (lack of information, again), the available empirical methodology does not consider different types of relations between variables, and so on. In our opinion, much more can be made in this field, to identify factors able to improve the specification of the Ohlson model, applied to certain industries, and even to certain regions or countries. 


\section{References}

AHMED, A.S. and TAKEDA, C. [1995]: "Stock market valuation of gains and losses on commercial banks' investment securities: An empirical analysis”, Journal of Accounting and Economics, 20: 207-225.

AKERLOF, G. [1970]: "The Market for Lemons: Qualitative Uncertainty and the Market Mechanism", The Quarterly Journal of Economics, 84, 3: 488-500.

ALLEN, F. and GALE, D. [2004]: "Competition and Financial Stability", Journal of Money, Credit and Banking, 36, 3: 453-480.

ALLEN, F. and SANTOMERO, A.M. [2001]: "What do financial intermediaries do?", Journal of Banking \& Finance, 25, 2: 271-294.

ATANASOGLOU, PP, BRISSIMIS, S.N., and DELIS, M.D. (2005): "Bank-specific, industry-specific and macroeconomic determinants of bank profitability", Working Paper No. 25, June, Bank of Greece.

BARTH, M.E.; BEAVER, W.H. and WOLFSON, M.A. [1990]: "Components of Earnings and the Structure of Bank Share Prices", Financial Analysts Journal, 46, 3 May/June-: 53-60.

BASU, S. [1997]: "The Conservatism Principle and the Asymmetric Timeliness of Earnings", Journal of Accounting and Economics, 24, 1: 3-37.

BEAVER, W. H. (1999): "Comments on 'An empirical assessment of the residual income valuation model' ", Journal of Accounting and Economics, Vol. 26, no 1-3, pp. $35-42$.

BEAVER, W.H.; EGER, C.; RYAN, S.G. and WOLFSON, M.A. [1989]: "Financial Reporting, Supplemental Disclosures and Bank Share Prices", Journal of Accounting Research, 27, 2 (Autumn): 157-178.

BEAVER, W.H. and RYAN, S.G. [2000]: "Biases and lags in book value and their effects on the ability of the book-to-market ratio to predict book return on equity", Journal of Accounting Research, 38, 1, Spring: 127-148.

BEGLEY, J.; CHAMBERLAIN, S.L. and LI, Y.-H. [2003]: "Modeling Goodwill for Banks: A Residual Income Approach with Empirical Tests", Working Paper.

BERGER, A.N. and HANNAN, T.H. [1989]: "The Price-Concentration Relationship in Banking", Review of Economics and Statistics, 71, 2: 291-299.

BERGER, A., and UDELL, G. [2002]: "Small Business Credit Availability and Relationship Lending: The Importance of Bank Organisational Structure”, The Economic Journal (Royal Economic Society), 112, 477: F32-F53. 
BOWEN, R.M. and SHORES, D. [2002]: "Determinants of Economic and Accounting Components of Residual Income: An Application to the Pharmaceutical Industry", Working Paper.

Burgstahler, D.C.; Dichev, I.D. [1997]: “Earnings, Adaptation and Equity Value”, The Accounting Review, 72, 2(April): 187-215.

BRICKLEY, J.A.; LINCK, J.S. and SMITH, C.W. [2003]: "Boundaries of the firm: evidence from the banking industry", Journal of Financial Economics, 70, 3: 351-383.

CALEM, P.S. [1994]: "The impact of geographic deregulation on small banks", Federal Reserve Bank of Philadelphia Business Review, Nov-Dec: 17-31.

CABRAL, L.M.B. and SANTOS, J.A.C. [2001]: "Cross Selling and Banking Efficiency", Working Paper, October. http://ssrn.com/abstract=289442

CHENG, Q. [2005]: "What Determines Residual Income?", The Accounting Review, 80, 1: $85-112$.

CLAESSENS, S. and LAEVEN, L. [2004]: "What Drives Bank Competition? Some International Evidence", Journal of Money, Credit and Banking, 36: 563-592.

DANBOLT, J. and REES, W. [2002]: "The Valuation of European Financial Firms", Review of Accounting and Finance, 1, 1: 5-24.

DEMIRGÜÇ-KUNT, A.; LAEVEN, L. and LEVINE, R. [2004]: "Regulations, Market Structure, Institutions and the Cost of Financial Intermediation", Journal of Money, Credit and Banking, 36: 593-626.

DEYOUNG, R.; HUNTER, W.C. and UDELL, G.F. [2004]: "The Past, Present, and Probable Future for Community Banks", Journal of Financial Services Research, 25, 2 3: 85-133.

ECB [2000]: "EU banks' income structure", Working Paper, European Central Bank, April.

ELLIOTT, J.A.; HANNA, J.D. and SHAW, W.H. [1991]: "The evaluation by the financial markets of changes in bank loan loss reserve levels", The Accounting Review, 66, 4: 847-861.

FINANCIAL ACCOUNTING STANDARDS BOARD (FASB) [1980]: "Qualitative characteristics of accounting information", Statement of concepts No. 2, Stamford: FASB.

FELTHAM, G.A. and OHLSON, J.A. [1995]: "Valuation and clean surplus accounting for operating and financial activities", Contemporary Accounting Research, 11, 2, Spring: 689-731.

FELTHAM, G.A. and OHLSON, J.A. [1996]: "Uncertainty resolution and the theory of depreciation measurement”, Journal of Accounting Research, 34, Autumn: 209-234. 
GJESDAL, F. (1999): “A Steady State Growth Valuation Model: A Note on Accounting and Valuation”, Working paper, Norwegian School of Economics.

GODDARD, J.A.; MOLYNEUX, P. and WILSON, J.O.S. [2004a]: "Dynamics of Growth and Profitability in Banking", Journal of Money, Credit and Banking, 36, 6: 1069-1090.

GODDARD, J.; MOLYNEUX, P. and WILSON, J.O.S. [2004b]: "The profitability of European banks: a cross-sectional and dynamic panel analysis", The Manchester School, 72, 3: 363-381.

GRIFFIN, P. A. and WALLACH, S. [1991]: "Latin American lending by major U.S. banks: The effects of disclosures about nonaccrual loans and Loan Loss Provisions", The Accounting Review, Vol. 66, 4: 830-846.

HANNAN, T.H. [1991]: "Bank commercial loan markets and the role of market structure: evidence from surveys of commercial lending", Journal of Banking \& Finance, 15, 1: 133-149.

KANAGARETNAM, K.; LOBO, G.L. and YANG, D.-H. [2004]: "Joint Tests of Signaling and Income Smoothing through Bank Loan Loss Provisions", Contemporary Accounting Research, 21, 4: 843-884.

KOHLBECK, M. [2004]: "Investor Valuations and Measuring Bank Intangible Assets", Journal of Accounting, Auditing \& Finance, 19, 1: 29-60.

KOHLBECK, M. and WARFIELD, T. [2002]: "The Role of Unrecorded Intangible Assets in Residual Income Valuation: The Case of Banks", Working Paper.

KOTHARI, S.P. [2001]: “Capital Markets Research in Accounting”, Journal of Accounting and Economics, Vol. 31, n 1-3 (September), pp. 105-231.

LA PORTA, R.L.; LOPEZ-DE-SILANES, F.; SHLEIFER, A. and VISHNY, R.W. [1997]: "Legal Determinants of External Finance", Journal of Finance, 52, 3: 11311150 .

LA PORTA, R.; LOPEZ-DE-SILANES, F.; SHLEIFER, A. and VISHNY, R.W. [1998]: "Law and Finance", Journal of Political Economy, 106, 6: 1113-1155.

NAKAMURA, L.I. [1994]: "Small borrowers and the survival of the small bank: is mouse bank Mighty or Mickey?", Federal Reserve Bank of Philadelphia Business Review, Nov-Dec: 3-15.

NEUMARK, D. and SHARPE, S.A. [1994]: "Market Structure and the Nature of Price Rigidity: Evidence from the Market for Consumer Deposits", The Quarterly Journal of Economics, 107, 2: 657-680.

OHLSON, J. A. (1995): “Earnings, Book Values, and Dividends in Equity Valuation”, Contemporary Accounting Research, Vol. 11, nº 2 (Spring), pp. 681-687. 
PENMAN, S.H. and ZHANG, X.-J. (2002): “Accounting conservatism, the quality of earnings, and stock returns“, The Accounting Review, 77, 2, April: 237-264.

SCHMIDT, R.H.; HACKETHAL, A., and TYRELL, M. [1999]: "Disintermediation and the Role of Banks in Europe: An International Comparison", Journal of Financial Intermediation, 8, 1-2: 36-67.

SPENCE, M.A. [1973]: "Job Market Signaling", The Quarterly Journal of Economics, 87, 3: 355-374.

STULZ, R.M. and WILLIAMSON, R. [2003]: "Culture, openness, and finance", Journal of Financial Economics, 70, 3: 313-349.

WAHLEN, J.M. [1994]: "The nature of information in commercial bank loan loss disclosures", The Accounting Review, 69, 3: 455-478.

WARFIELD, T.D. and LINSMEIER, T.J. [1992]: "Tax planing, earnings management, and the differential information content of bank earnings components", The Accounting Review, 67, July: 546-562.

WATTS, R.L. [2003]: "Conservatism in accounting. Part I: Explanations and implications”, Accounting Horizons, 17, 3, September: 207-221.

WILSON, J. and WILLIAMS, J. [2000]: "The size and growth of banks: evidence from four European countries", Applied Economics, 32, 9.

ZHANG, X.-J. [2000]: "Conservative accounting and equity valuation", Journal of Accounting and Economics, 29, 1: 125-149. 


\section{Appendix}

Table 1-. Variables Used: Description and source

\begin{tabular}{|c|c|c|}
\hline Variable & Name & Description [Source] \\
\hline Comp & Company & [BankScope] \\
\hline CTRYCODE & Country code & [BankScope] \\
\hline ROE & Return on Equity & Net Income (t) / Equity (t-1) [Bankscope] \\
\hline LLLP & Loan Loss Provision Ratio & Loan Loss Provission (t) / Loans (t) [Bankscope] \\
\hline SIZE & Size & Logarithm ofTotal Assets (t) [Bankscope] \\
\hline LEV & Leverage Ratio & (Total Assets - Equity) / Total Assets [Bankscope] \\
\hline MGE & Management Efficiency & $\begin{array}{l}\text { Total Earning Assets (t) / Total Assets }(\mathrm{t}) \\
\text { [Bankscope] }\end{array}$ \\
\hline LIQ & Liquidity of Assets & $\begin{array}{l}\text { Liquid Assets (Memo) (t) / Total Assets (t) } \\
\text { [Bankscope] }\end{array}$ \\
\hline FEE & Fee Income & $\begin{array}{l}\text { Other Operating Income (t) / Total Assets (t-1) } \\
\text { [Bankscope] }\end{array}$ \\
\hline OVER & Overheads Ratio & Overheads (t) / Total Assets (t-1) [Bankscope] \\
\hline DLTIR & One-Year Change of Long Term Interest Rates & $\begin{array}{l}\text { Long Term Interest Rates }(\mathrm{t}) \text { - Long Term Interest } \\
\text { Rates }(\mathrm{t}-1)[\mathrm{OECD}]\end{array}$ \\
\hline EF & Economic Freedom Index & 10 factors [The Heritage Foundation] $\left(^{*}\right)$ \\
\hline$\overline{A L}$ & $\begin{array}{l}\text { Applications for domestic commercial banking } \\
\text { licenses }\end{array}$ & $\begin{array}{l}\text { [World Bank Survey of Bank Regulation and } \\
\text { Supervision] }\end{array}$ \\
\hline$\overline{A D}$ & $\begin{array}{l}\text { Applications Dennied for domestic commercial } \\
\text { banking licenses }\end{array}$ & $\begin{array}{l}\text { [World Bank Survey of Bank Regulation and } \\
\text { Supervision] }\end{array}$ \\
\hline IA & Index of Applications Accepted & $1-(\mathrm{AD} / \mathrm{AL})[]$ \\
\hline SO & State Ownership & $\begin{array}{l}\text { [World Bank Survey of Bank Regulation and } \\
\text { Supervision] }\end{array}$ \\
\hline$\overline{A R}$ & Activity Range & $\begin{array}{l}4 \text { types of activities [World Bank Survey of Bank } \\
\text { Regulation and Supervision] }\end{array}$ \\
\hline ACTR & Activity Restrictions & $\begin{array}{l}\text { 4-AR [World Bank Survey of Bank Regulation and } \\
\text { Supervision] }\end{array}$ \\
\hline$\overline{A C}$ & Accounting Conservatism & $\begin{array}{l}\text { Dummy Variable of Accounting Rules }(1=\text { USA-UK- } \\
\text { International Standards; 0: Other Countries, i.e. } \\
\text { Local GAAP) }\end{array}$ \\
\hline $\mathrm{R}$ & Cost of Equity & $\begin{array}{l}\text { CAPM: Risk Premium = 4.5\%; Country Average One } \\
\text { Year Beta from Bankscope; Long Term Interest } \\
\text { Rates in the country }\end{array}$ \\
\hline AROE & Abnormal Roe & ROE - Cost of Equity \\
\hline TL & Total Loans in the Country & Country Aggregate Bank Loans [BankScope] \\
\hline MSL & Market Share of Loans & Loans of the Bank / TL [BankScope] \\
\hline AS & Average Size of Banks in the Country & [BankScope] \\
\hline
\end{tabular}

(*)The 2005 Index of Economic Freedom measures 161 countries against a list of 50 independent variables divided into 10 broad factors of economic freedom. Low scores are more desirable. The higher the score on a factor, the greater the level of government interference in the economy and the less economic freedom a country enjoys. 
Table 2-. Sample Composition

\begin{tabular}{lrrrr}
\hline Panel A: & \multicolumn{3}{c}{ Summary of Abnormal ROE by Year } \\
\cline { 2 - 5 } Year & Mean & \multicolumn{1}{l}{ Std. Dev. } & Freq. & Percent \\
\hline 1997 & 0.0097 & 0.1315 & 335 & $10.2 \%$ \\
1998 & 0.0135 & 0.1586 & 354 & $10.8 \%$ \\
1999 & 0.0293 & 0.1615 & 434 & $13.2 \%$ \\
2000 & 0.0131 & 0.1574 & 471 & $14.3 \%$ \\
2001 & -0.0096 & 0.1651 & 462 & $14.1 \%$ \\
2002 & -0.0078 & 0.1273 & 632 & $19.2 \%$ \\
2003 & 0.0221 & 0.1113 & 599 & $18.2 \%$ \\
\hline Total & $\mathbf{0 . 0 0 9 4}$ & $\mathbf{0 . 1 4 4 3}$ & $\mathbf{3 2 8 7}$ & $\mathbf{1 0 0 . 0 \%}$ \\
\hline
\end{tabular}

Panel B: Summary of Abnormal ROE by Country

Country Mean Std. Dev. Freq.

\begin{tabular}{lrrrc}
\hline AT & 0.0395 & 0.0744 & 66 & $2.0 \%$ \\
AU & 0.0078 & 0.1195 & 112 & $3.4 \%$ \\
BE & 0.0077 & 0.1554 & 61 & $1.9 \%$ \\
CA & 0.0037 & 0.1455 & 147 & $4.5 \%$ \\
CH & 0.0440 & 0.0873 & 133 & $4.0 \%$ \\
CZ & 0.0313 & 0.1678 & 14 & $0.4 \%$ \\
DE & -0.0010 & 0.1288 & 109 & $3.3 \%$ \\
DK & 0.0515 & 0.0954 & 82 & $2.5 \%$ \\
ES & 0.0365 & 0.1117 & 168 & $5.1 \%$ \\
FI & 0.0875 & 0.1434 & 37 & $1.1 \%$ \\
FR & 0.0531 & 0.1212 & 348 & $10.6 \%$ \\
GB & 0.0487 & 0.1283 & 273 & $8.3 \%$ \\
GR & -0.0297 & 0.0927 & 68 & $2.1 \%$ \\
HU & -0.0309 & 0.1824 & 30 & $0.9 \%$ \\
IE & 0.1105 & 0.1215 & 51 & $1.6 \%$ \\
IS & 0.0191 & 0.0580 & 11 & $0.3 \%$ \\
IT & 0.0195 & 0.1098 & 123 & $3.7 \%$ \\
JP & -0.0096 & 0.1275 & 566 & $17.2 \%$ \\
KR & -0.0484 & 0.1627 & 72 & $2.2 \%$ \\
LU & 0.0933 & 0.1012 & 29 & $0.9 \%$ \\
MX & -0.0916 & 0.1187 & 84 & $2.6 \%$ \\
NL & 0.0101 & 0.1265 & 92 & $2.8 \%$ \\
NO & 0.0239 & 0.1065 & 29 & $0.9 \%$ \\
NZ & 0.0618 & 0.1080 & 31 & $0.9 \%$ \\
PL & -0.0747 & 0.1357 & 45 & $1.4 \%$ \\
PT & 0.0668 & 0.0815 & 58 & $1.8 \%$ \\
SE & -0.0021 & 0.1247 & 18 & $0.5 \%$ \\
TR & -0.4470 & 0.2245 & 63 & $1.9 \%$ \\
US & 0.0206 & 0.1153 & 367 & $11.2 \%$ \\
\hline Total & $\mathbf{0 . 0 0 9 4}$ & $\mathbf{0 . 1 4 4 3}$ & $\mathbf{3 2 8 7}$ & $\mathbf{1 0 0 . 0 \%}$ \\
\hline & & & & \\
\hline
\end{tabular}


Table 3-. Descriptive Statistics

Panel A: Descriptive statistics for Firm analyses

\begin{tabular}{llrrrr}
\hline Variable & Obs & \multicolumn{1}{c}{ Mean } & Std. Dev. & \multicolumn{1}{l}{ Min } & \multicolumn{1}{c}{ Max } \\
\hline aroe & 3287 & 0.0094 & 0.1443 & -1.0005 & 0.4418 \\
IIlp & 3088 & 0.0091 & 0.0374 & -0.7333 & 0.9726 \\
size & 3287 & 15.4441 & 2.1276 & 6.7396 & 20.7754 \\
lev & 3287 & 0.9087 & 0.0989 & 0.0000 & 1.4687 \\
mge & 3285 & 0.9115 & 0.0888 & 0.0312 & 0.9964 \\
liq & 3181 & 0.1810 & 0.1852 & -0.0214 & 1.0000 \\
fee & 3100 & 0.0241 & 0.0585 & -0.1444 & 1.0375 \\
over & 3100 & 0.0350 & 0.0489 & 0.0006 & 0.7490 \\
\hline
\end{tabular}

Panel B: Descriptive statistics for Industry analyses

\begin{tabular}{llrrrr}
\hline Variable & Obs & \multicolumn{1}{c}{ Mean } & Std. Dev. & \multicolumn{1}{l}{ Min } & \multicolumn{1}{l}{ Max } \\
\hline msl & 3262 & 0.0441 & 0.0981 & 0.0000 & 0.9148 \\
ef & 3287 & 2.1888 & 0.3541 & 1.6000 & 3.5000 \\
ia & 2584 & 0.9459 & 0.1263 & 0.2857 & 1.0000 \\
so & 2888 & 0.0458 & 0.0938 & 0.0000 & 0.3997 \\
actr & 3287 & 0.8718 & 0.7010 & 0.0000 & 2.0000 \\
as & 3287 & 15.4203 & 0.9648 & 12.0258 & 18.8854 \\
dltir & 3287 & -0.0069 & 0.0314 & -0.3127 & 0.2754 \\
ac & 3287 & 0.5135 & 0.4999 & 0.0000 & 1.0000 \\
\hline
\end{tabular}

Table 4-. Correlations

\begin{tabular}{|c|c|c|c|c|c|c|c|c|c|c|c|c|c|c|c|c|}
\hline & aroe & dltir & IIIp & size & lev & liq & mge & fee & over & msl & ef & ia & so & actr & as & ac \\
\hline aroe & 1 & & & & & & & & & & & & & & & \\
\hline dltir & $0.1375^{\star}$ & 1 & & & & & & & & & & & & & & \\
\hline IIIp & $-0.0960^{\star}$ & 0.0019 & 1 & & & & & & & & & & & & & \\
\hline size & 0.0236 & $0.0400^{*}$ & 0.0019 & 1 & & & & & & & & & & & & \\
\hline lev & $0.0361^{*}$ & $0.0682^{\star}$ & 0.0154 & $0.5179^{*}$ & 1 & & & & & & & & & & & \\
\hline liq & $-0.0396^{\star}$ & $-0.1281^{\star}$ & -0.0076 & $-0.2315^{\star}$ & $-0.2489 *$ & 1 & & & & & & & & & & \\
\hline mge & $0.0653^{\star}$ & $0.0569 *$ & $-0.1363^{\star}$ & $0.1423^{\star}$ & $0.3828^{\star}$ & $-0.1027^{*}$ & 1 & & & & & & & & & \\
\hline fee & $0.0764^{\star}$ & -0.0002 & $0.0815^{\star}$ & $-0.2066^{*}$ & \begin{tabular}{|l|}
$-0.3568^{*}$ \\
\end{tabular} & $0.1930^{*}$ & $-0.3190^{*}$ & 1 & & & & & & & & \\
\hline over & -0.0135 & $-0.0539 *$ & $0.1306^{*}$ & $-0.3020^{\star}$ & $-0.3682^{*}$ & $0.1545^{\star}$ & $-0.3907^{*}$ & $0.8027^{*}$ & 1 & & & & & & & \\
\hline msl & 0.006 & -0.0255 & -0.0101 & $0.4798^{\star}$ & $0.1539 \star$ & -0.0086 & $-0.0628^{\star}$ & $-0.0467^{*}$ & $-0.0478^{*}$ & 1 & & & & & & \\
\hline ef & $-0.2639^{\star}$ & $-0.2915^{\star}$ & $0.1009^{*}$ & $0.0593^{*}$ & 0.0001 & 0.0316 & $-0.1066^{\star}$ & 0.0242 & $0.0582^{*}$ & $0.0348^{\star}$ & 1 & & & & & \\
\hline ia & $0.3793^{\star}$ & $0.4136^{*}$ & $-0.0489^{*}$ & $0.0668^{\star}$ & $0.1180^{*}$ & $-0.3108^{*}$ & $0.0962^{*}$ & 0.0312 & $-0.0841^{*}$ & $-0.1081^{*}$ & \begin{tabular}{|c|}
$-0.3775^{\star}$ \\
\end{tabular} & 1 & & & & \\
\hline so & $-0.2498^{*}$ & $-0.2350^{*}$ & $0.0956^{*}$ & 0.0174 & -0.0355 & $0.2036^{*}$ & $-0.1165^{\star}$ & $0.0594^{*}$ & $0.0897^{*}$ & $0.1237^{*}$ & $0.4689^{*}$ & $\mid-0.3839 *$ & 1 & & & \\
\hline actr & -0.0226 & $0.0845^{*}$ & -0.0131 & $0.0765^{\star}$ & $0.1475^{*}$ & $-0.2181^{*}$ & $0.1087^{*}$ & $-0.1042^{*}$ & $-0.1116^{*}$ & $-0.0421^{*}$ & $-0.1227^{\star}$ & $0.2127^{*}$ & 0.004 & 1 & & \\
\hline as & 0.0319 & $0.0848^{*}$ & 0.0327 & $0.4548^{*}$ & $0.2718^{*}$ & $-0.1678^{*}$ & $0.2014^{*}$ & $-0.1221^{*}$ & $-0.1941^{*}$ & 0.0263 & $0.0958^{*}$ & $0.1670^{*}$ & $0.0370^{*}$ & $0.1747^{*}$ & 1 & \\
\hline ac & $-0.1634^{\star}$ & $-0.0543^{\star}$ & 0.0076 & 0.0184 & 0.0078 & $-0.2129^{\star}$ & -0.0112 & $-0.0484^{*}$ & $-0.0554^{*}$ & $-0.0733^{*}$ & $-0.1508^{\star}$ & $0.0438^{\star}$ & -0.0304 & $0.4324^{*}$ & 0.0273 & 1 \\
\hline
\end{tabular}


Table 5-. Regression Analysis: Cross Sectional Regressions (pooled) Dependent variable: Current Abnormal ROE

\begin{tabular}{|c|c|c|c|c|c|c|}
\hline & Firm Level & $\begin{array}{c}\text { Industry: } \\
\text { Substitutes } \\
\text { and Threat of } \\
\text { Entry }\end{array}$ & $\begin{array}{c}\text { Industry: } \\
\text { Rivalry } \\
\text { between } \\
\text { Established } \\
\text { Competitors }\end{array}$ & $\begin{array}{l}\text { Industry: } \\
\text { Bargaining } \\
\text { Power of } \\
\text { Customers }\end{array}$ & $\begin{array}{l}\text { Industry: } \\
\text { Bargaining } \\
\text { Power of } \\
\text { Suppliers }\end{array}$ & $\begin{array}{l}\text { Economy: } \\
\text { Accounting } \\
\text { Conservatism } \\
\text { and Interest } \\
\text { Rates }\end{array}$ \\
\hline \multirow[t]{2}{*}{ IIIp } & -0.297 & -0.29 & -0.331 & -0.308 & -0.36 & -0.369 \\
\hline & {$[3.01]^{* *}$} & {$[2.96]^{\star *}$} & {$[2.79]^{\star *}$} & {$[2.46]^{*}$} & {$[2.65]^{\star *}$} & {$[2.71]^{\star \star}$} \\
\hline \multirow[t]{2}{*}{ size } & -0.002 & -0.003 & -0.005 & -0.004 & -0.006 & -0.004 \\
\hline & [1.24] & [1.63] & {$[2.30]^{\star}$} & [1.86] & {$[2.51]^{\star}$} & {$[1.86$} \\
\hline \multirow[t]{2}{*}{ lev } & 0.08 & 0.086 & 0.088 & 0.076 & 0.129 & 0.105 \\
\hline & [1.68] & [1.78] & [1.24] & [1.04] & [1.73] & [1.45] \\
\hline \multirow[t]{2}{*}{ mge } & 0.052 & 0.062 & 0.015 & 0.009 & -0.025 & 0.03 \\
\hline & [1.22] & [1.40] & [0.25] & [0.15] & [0.35] & {$[0.42]$} \\
\hline \multirow[t]{2}{*}{ liq } & -0.036 & -0.04 & 0.001 & 0.017 & -0.004 & -0.059 \\
\hline & [1.71] & [1.89] & {$[0.06]$} & [0.78] & {$[0.17]$} & {$[2.28]^{*}$} \\
\hline \multirow[t]{2}{*}{ fee } & 0.548 & 0.556 & 0.415 & 0.426 & 0.586 & 0.556 \\
\hline & {$[3.88]^{\star \star}$} & {$[3.90]^{\star \star}$} & {$[3.38]^{\star \star}$} & {$[3.50]^{\star \star}$} & {$[3.00]^{\star \star}$} & {$[3.07]^{\star \star}$} \\
\hline \multirow[t]{2}{*}{ over } & -0.345 & -0.356 & -0.293 & -0.302 & -0.429 & -0.347 \\
\hline & {$[2.26]^{*}$} & {$[2.29]^{\star}$} & [1.88] & [1.95] & {$[2.33]^{\star}$} & {$[1.99]^{*}$} \\
\hline \multirow[t]{2}{*}{$\mathrm{msl}$} & & 0.058 & 0.111 & 0.093 & 0.137 & 0.097 \\
\hline & & {$[2.49]^{*}$} & {$[4.05]^{\star *}$} & {$[3.43]^{\star \star}$} & {$[4.70]^{\star \star}$} & {$[3.19]^{\star \star}$} \\
\hline \multirow[t]{2}{*}{ as } & & -0.002 & -0.005 & -0.002 & 0.004 & 0.008 \\
\hline & & [0.82] & [1.54] & {$[0.63]$} & [1.07] & {$[2.21]^{*}$} \\
\hline \multirow[t]{2}{*}{ ia } & & & 0.321 & 0.269 & 0.157 & 0.132 \\
\hline & & & {$[8.03]^{\star \star}$} & {$[6.75]^{\star \star}$} & {$[3.96]^{\star \star}$} & {$[2.80]^{\star \star}$} \\
\hline \multirow[t]{2}{*}{ ef } & & & & -0.054 & -0.07 & -0.094 \\
\hline & & & & {$[5.64]^{\star \star}$} & {$[4.94]^{\star *}$} & {$[6.63]^{\star \star}$} \\
\hline \multirow[t]{2}{*}{ so } & & & & & -0.177 & -0.154 \\
\hline & & & & & {$[3.71]^{\star \star}$} & {$[3.17]^{\star \star}$} \\
\hline \multirow[t]{2}{*}{ actr } & & & & & -0.005 & 0.016 \\
\hline & & & & & [0.85] & {$[2.44]^{*}$} \\
\hline \multirow[t]{2}{*}{ ac } & & & & & & -0.069 \\
\hline & & & & & & {$[7.49]^{\star \star}$} \\
\hline \multirow[t]{2}{*}{ DLTIR } & & & & & & -0.117 \\
\hline & & & & & & [0.44] \\
\hline \multirow[t]{2}{*}{ Constant } & -0.07 & -0.034 & -0.239 & -0.114 & -0.042 & -0.063 \\
\hline & [1.36] & {$[0.58]$} & {$[2.90]^{\star *}$} & [1.35] & {$[0.48]$} & {$[0.71]$} \\
\hline Observations & 2844 & 2844 & 2249 & 2249 & 1907 & 1907 \\
\hline R-squared & 0.03 & 0.03 & 0.1 & 0.11 & 0.15 & 0.19 \\
\hline
\end{tabular}

Robust t statistics in brackets

* significant at $5 \%$; ** significant at $1 \%$ 
Table 6-. Non-lineal cross-sectional regressions (pooled) Dependent variable: Current Abnormal ROE

\begin{tabular}{|c|c|c|c|c|c|c|}
\hline & Firm Level & $\begin{array}{l}\text { Industry: } \\
\text { Substitutes and } \\
\text { Threat of Entry }\end{array}$ & $\begin{array}{c}\text { Industry: } \\
\text { Rivalry between } \\
\text { Established } \\
\text { Competitors }\end{array}$ & $\begin{array}{l}\text { Industry: } \\
\text { Bargaining } \\
\text { Power of } \\
\text { Customers }\end{array}$ & $\begin{array}{l}\text { Industry: } \\
\text { Bargaining } \\
\text { Power of } \\
\text { Suppliers }\end{array}$ & $\begin{array}{l}\text { Economy: } \\
\text { Accounting } \\
\text { Conservatism } \\
\text { and Interest } \\
\text { Rates }\end{array}$ \\
\hline \multirow[t]{2}{*}{ IIIp } & -0.199 & -0.2 & -0.246 & -0.244 & -0.342 & -0.341 \\
\hline & [1.25] & [1.25] & [1.54] & [1.48] & {$[1.87]$} & [1.85] \\
\hline \multirow[t]{2}{*}{ size } & 0 & -0.001 & -0.003 & -0.002 & -0.007 & -0.007 \\
\hline & {$[0.17]$} & [0.34] & {$[1.07]$} & {$[0.83]$} & {$[2.18]^{\star}$} & {$[2.18]^{\star}$} \\
\hline \multirow[t]{2}{*}{ lev } & 0.05 & 0.055 & 0.018 & 0.012 & 0.091 & 0.09 \\
\hline & {$[0.93]$} & [1.01] & {$[0.24]$} & {$[0.15]$} & {$[1.53]$} & [1.50] \\
\hline \multirow[t]{2}{*}{ mge } & 0.116 & 0.119 & 0.182 & 0.173 & 0.133 & 0.134 \\
\hline & [1.74] & [1.79] & {$[2.25]^{\star}$} & {$[2.17]^{*}$} & [1.51] & [1.51] \\
\hline \multirow[t]{2}{*}{ liq } & 0.029 & 0.025 & 0.023 & 0.019 & 0.018 & 0.019 \\
\hline & [1.49] & [1.27] & [0.99] & {$[0.80]$} & {$[0.69]$} & {$[0.72]$} \\
\hline \multirow[t]{2}{*}{ fee } & 0.185 & 0.186 & 0.182 & 0.192 & 0.288 & 0.287 \\
\hline & {$[2.07]^{\star}$} & {$[2.07]^{\star}$} & [1.95] & {$[2.08]^{\star}$} & [1.47] & [1.47] \\
\hline \multirow[t]{2}{*}{ over } & 0.088 & 0.081 & 0.062 & 0.045 & 0.017 & 0.017 \\
\hline & {$[0.62]$} & {$[0.57]$} & {$[0.35]$} & {$[0.25]$} & {$[0.09]$} & {$[0.08]$} \\
\hline \multirow[t]{2}{*}{ ac } & 0.144 & 0.42 & -0.017 & 0.119 & 0.177 & 0.134 \\
\hline & [1.25] & {$[2.76]^{\star \star}$} & {$[0.09]$} & {$[0.60]$} & {$[0.68]$} & [0.52] \\
\hline \multirow[t]{2}{*}{ aclllp } & -0.237 & -0.19 & -0.325 & -0.202 & -0.033 & 0.019 \\
\hline & {$[0.93]$} & {$[0.76]$} & [1.16] & {$[0.74]$} & {$[0.12]$} & {$[0.07]$} \\
\hline \multirow[t]{2}{*}{ acsize } & -0.007 & -0.006 & -0.003 & -0.002 & 0.004 & 0.004 \\
\hline & {$[2.28]^{\star}$} & [1.58] & {$[0.65]$} & {$[0.39]$} & {$[0.90]$} & {$[0.90]$} \\
\hline \multirow[t]{2}{*}{ aclev } & 0.097 & 0.112 & 0.27 & 0.191 & 0.036 & 0.024 \\
\hline & {$[0.92]$} & [1.05] & [1.48] & {$[0.98]$} & [0.19] & {$[0.13]$} \\
\hline \multirow[t]{2}{*}{ acmge } & -0.122 & -0.07 & -0.137 & -0.077 & 0.082 & 0.073 \\
\hline & {$[1.36]$} & {$[0.77]$} & {$[1.00]$} & {$[0.57]$} & {$[0.52]$} & {$[0.47]$} \\
\hline \multirow[t]{2}{*}{ acliq } & -0.217 & -0.231 & -0.128 & -0.045 & -0.065 & -0.068 \\
\hline & {$[4.98]^{\star \star}$} & {$[5.28]^{\star \star}$} & {$[2.32]^{\star}$} & {$[0.85]$} & {$[1.12]$} & [1.16] \\
\hline \multirow[t]{2}{*}{ acfee } & 1.443 & 1.569 & 0.885 & 0.827 & 0.788 & 0.752 \\
\hline & {$[4.15]^{\star \star}$} & {$[4.52]^{\star *}$} & {$[2.19]^{\star}$} & {$[1.98]^{\star}$} & [1.73] & [1.83] \\
\hline acover & -1.508 & -1.664 & -0.945 & -0.912 & -0.913 & -0.888 \\
\hline & {$[4.58]^{\star \star}$} & {$[4.98]^{\star *}$} & {$[2.41]^{\star}$} & {$[2.30]^{\star}$} & {$[2.27]^{\star}$} & {$[2.42]^{\star}$} \\
\hline msl & & 0.011 & 0.026 & 0.015 & 0.106 & 0.106 \\
\hline & & {$[0.46]$} & {$[0.98]$} & {$[0.54]$} & {$[3.71]^{\star \star}$} & {$[3.70]^{\star \star}$} \\
\hline as & & 0.011 & 0.014 & 0.013 & 0.029 & 0.029 \\
\hline & & [1.71] & {$[1.99]^{\star}$} & [1.95] & {$[3.61]^{\star \star}$} & {$[3.63]^{\star \star}$} \\
\hline acmsl & & 0.134 & 0.23 & 0.158 & 0.082 & 0.086 \\
\hline & & {$[2.39]^{\star}$} & {$[3.60]^{\star \star}$} & {$[2.39]^{\star}$} & [1.15] & [1.21] \\
\hline acas & & -0.023 & -0.028 & -0.013 & -0.033 & -0.032 \\
\hline & & {$[3.07]^{\star \star}$} & {$[3.33]^{\star \star}$} & [1.49] & {$[3.37]^{\star \star}$} & {$[3.25]^{\star \star}$} \\
\hline ia & & & 0.011 & 0.013 & -0.1 & -0.101 \\
\hline & & & {$[0.26]$} & {$[0.31]$} & {$[1.57]$} & [1.58] \\
\hline acia & & & 0.365 & 0.212 & 0.439 & 0.513 \\
\hline & & & {$[5.70]^{\star \star}$} & {$[3.20]^{\star *}$} & {$[2.65]^{\star *}$} & {$[2.97]^{\star \star}$} \\
\hline ef & & & & -0.025 & -0.01 & -0.009 \\
\hline & & & & [1.91] & [0.42] & {$[0.40]$} \\
\hline acef & & & & -0.113 & -0.106 & -0.117 \\
\hline & & & & {$[4.83]^{\star \star}$} & {$[3.09]^{\star *}$} & {$[3.41]^{\star \star}$} \\
\hline so & & & & & -0.337 & -0.333 \\
\hline & & & & & {$[3.70]^{\star *}$} & {$[3.72]^{\star \star}$} \\
\hline actr & & & & & 0.007 & 0.007 \\
\hline & & & & & {$[0.85]$} & {$[0.83]$} \\
\hline acso & & & & & 0.348 & 0.349 \\
\hline & & & & & {$[2.90]^{\star \star}$} & {$[2.95]^{\star \star}$} \\
\hline acactr & & & & & -0.042 & -0.05 \\
\hline & & & & & {$[1.05]$} & [1.23] \\
\hline DLTIR & & & & & & 0.142 \\
\hline & & & & & & {$[0.38]$} \\
\hline acdltir & & & & & & -0.509 \\
\hline & & & & & & {$[1.20]$} \\
\hline Constant & -0.136 & -0.302 & -0.345 & -0.277 & -0.417 & -0.412 \\
\hline & [1.63] & {$[2.37]^{*}$} & {$[2.42]^{\star}$} & [1.91] & [1.91] & [1.89] \\
\hline Observations & 2844 & 2844 & 2249 & 2249 & 1907 & 1907 \\
\hline R-squared & 0.09 & 0.09 & 0.16 & 0.19 & 0.23 & 0.23 \\
\hline
\end{tabular}


Table 7-. Panel Data (cross-sectional time series): Current ROE

Panel-Data: Random-effects GLS regression

Dependent variable: Current Abnormal ROE

\begin{tabular}{|c|c|c|c|c|c|c|}
\hline & Firm & $\begin{array}{c}\text { Industry: } \\
\text { Substitutes } \\
\text { and Threat of } \\
\text { Entry }\end{array}$ & $\begin{array}{l}\text { Industry: } \\
\text { Rivalry } \\
\text { between } \\
\text { Established } \\
\text { Competitors }\end{array}$ & $\begin{array}{l}\text { Industry: } \\
\text { Bargaining } \\
\text { Power of } \\
\text { Customers }\end{array}$ & $\begin{array}{l}\text { Industry: } \\
\text { Bargaining } \\
\text { Power of } \\
\text { Suppliers }\end{array}$ & $\begin{array}{c}\text { Economy: } \\
\text { Accounting } \\
\text { Conservatism } \\
\text { and Interest } \\
\text { Rates }\end{array}$ \\
\hline \multirow[t]{2}{*}{ IIlp } & -0.194 & -0.195 & -0.254 & -0.254 & -0.328 & -0.326 \\
\hline & [1.95] & [1.94] & {$[2.01]^{\star}$} & {$[1.96]^{*}$} & {$[2.37]^{\star}$} & {$[2.34]^{*}$} \\
\hline \multirow[t]{2}{*}{ size } & 0.003 & 0 & -0.002 & -0.002 & -0.004 & -0.003 \\
\hline & [1.20] & [0.03] & [0.61] & {$[0.53]$} & [1.29] & [1.04] \\
\hline \multirow[t]{2}{*}{ lev } & -0.005 & 0.001 & -0.035 & -0.037 & 0.045 & 0.041 \\
\hline & [0.08] & [0.01] & [0.40] & [0.42] & {$[0.50]$} & [0.46] \\
\hline \multirow[t]{2}{*}{ mge } & 0.05 & 0.047 & 0.085 & 0.086 & 0.051 & 0.076 \\
\hline & [1.06] & [0.98] & [1.15] & [1.16] & {$[0.61]$} & [0.95] \\
\hline \multirow[t]{2}{*}{ liq } & -0.045 & -0.045 & 0.007 & 0.012 & -0.002 & -0.046 \\
\hline & [1.77] & [1.76] & {$[0.26]$} & {$[0.48]$} & {$[0.05]$} & [1.55] \\
\hline \multirow[t]{2}{*}{ fee } & 0.469 & 0.468 & 0.345 & 0.361 & 0.534 & 0.491 \\
\hline & {$[2.81]^{\star *}$} & {$[2.79]^{\star *}$} & {$[2.22]^{\star}$} & {$[2.31]^{*}$} & {$[2.19]^{\star}$} & {$[2.30]^{*}$} \\
\hline \multirow[t]{2}{*}{ over } & -0.362 & -0.363 & -0.208 & -0.216 & -0.38 & -0.328 \\
\hline & [1.92] & [1.92] & [1.09] & [1.14] & [1.74] & [1.61] \\
\hline \multirow[t]{2}{*}{$\mathrm{msl}$} & & 0.059 & 0.113 & 0.105 & 0.141 & 0.107 \\
\hline & & [1.61] & {$[2.83]^{\star \star}$} & {$[2.64]^{\star \star}$} & {$[3.44]^{\star \star}$} & {$[2.59]^{\star \star}$} \\
\hline \multirow[t]{2}{*}{ as } & & 0.006 & 0.002 & 0.004 & 0.008 & 0.012 \\
\hline & & [1.50] & [0.41] & {$[0.77]$} & {$[1.70]$} & {$[2.56]^{*}$} \\
\hline \multirow[t]{2}{*}{ ia } & & & 0.379 & 0.328 & 0.207 & 0.196 \\
\hline & & & {$[7.73]^{\star \star}$} & {$[6.32]^{\star \star}$} & {$[3.94]^{\star \star}$} & {$[3.41]^{\star \star}$} \\
\hline \multirow[t]{2}{*}{ ef } & & & & -0.043 & -0.071 & -0.084 \\
\hline & & & & {$[3.56]^{\star \star}$} & {$[4.02]^{\star \star}$} & {$[4.96]^{\star \star}$} \\
\hline \multirow[t]{2}{*}{ so } & & & & & -0.164 & -0.171 \\
\hline & & & & & {$[2.47]^{\star}$} & {$[2.60]^{\star \star}$} \\
\hline \multirow[t]{2}{*}{ actr } & & & & & -0.009 & 0.015 \\
\hline & & & & & [1.02] & [1.69] \\
\hline \multirow[t]{2}{*}{ ac } & & & & & & -0.071 \\
\hline & & & & & & {$[6.31]^{\star \star}$} \\
\hline \multirow[t]{2}{*}{ DLTIR } & & & & & & -0.285 \\
\hline & & & & & & [1.26] \\
\hline \multirow[t]{2}{*}{ Constant } & -0.063 & -0.118 & -0.404 & -0.288 & -0.176 & -0.212 \\
\hline & [1.02] & [1.57] & {$[3.67]^{\star \star}$} & {$[2.53]^{*}$} & [1.52] & [1.89] \\
\hline Observations & 2844 & 2844 & 2249 & 2249 & 1907 & 1907 \\
\hline Number of Banks & 745 & 745 & 590 & 590 & 505 & 505 \\
\hline
\end{tabular}

Robust $z$ statistics in brackets

* significant at $5 \%$; ** significant at $1 \%$ 
Table 8-. Panel Data (cross-sectional time series): Future $t+1$ abnormal ROE Panel-Data: Random-effects GLS regression

Dependent variable: Future ( $\mathrm{t}+1)$ Abnormal ROE

\begin{tabular}{|c|c|c|c|c|c|c|}
\hline & Firm & $\begin{array}{c}\text { Industry: } \\
\text { Substitutes } \\
\text { and Threat of } \\
\text { Entry }\end{array}$ & $\begin{array}{c}\text { Industry: } \\
\text { Rivalry } \\
\text { between } \\
\text { Established } \\
\text { Competitors }\end{array}$ & $\begin{array}{l}\text { Industry: } \\
\text { Bargaining } \\
\text { Power of } \\
\text { Customers }\end{array}$ & $\begin{array}{l}\text { Industry: } \\
\text { Bargaining } \\
\text { Power of } \\
\text { Suppliers }\end{array}$ & $\begin{array}{l}\text { Economy: } \\
\text { Accounting } \\
\text { Conservatism } \\
\text { and Interest } \\
\text { Rates }\end{array}$ \\
\hline IIIp & $\begin{array}{r}-0.041 \\
{[0.45]}\end{array}$ & $\begin{array}{r}-0.031 \\
{[0.34]}\end{array}$ & $\begin{array}{r}-0.019 \\
{[0.24]}\end{array}$ & $\begin{array}{r}-0.018 \\
{[0.23]}\end{array}$ & $\begin{array}{l}0.008 \\
{[0.09]} \\
\end{array}$ & $\begin{array}{r}-0.005 \\
{[0.06]}\end{array}$ \\
\hline size & $\begin{array}{r}-0.003 \\
{[1.03]} \\
\end{array}$ & $\begin{array}{c}-0.002 \\
{[0.87]} \\
\end{array}$ & $\begin{array}{r}-0.005 \\
{[1.57]} \\
\end{array}$ & $\begin{array}{r}-0.005 \\
{[1.52]} \\
\end{array}$ & $\begin{array}{r}-0.007 \\
{[1.93]} \\
\end{array}$ & $\begin{array}{r}-0.006 \\
{[1.69]} \\
\end{array}$ \\
\hline lev & $\begin{array}{l}0.083 \\
{[1.07]}\end{array}$ & $\begin{array}{l}0.091 \\
{[1.16]}\end{array}$ & $\begin{array}{l}0.146 \\
{[1.31]}\end{array}$ & $\begin{array}{l}0.145 \\
{[1.29]}\end{array}$ & $\begin{array}{l}0.237 \\
{[1.92]}\end{array}$ & $\begin{array}{l}0.231 \\
{[1.87]}\end{array}$ \\
\hline mge & $\begin{array}{l}0.031 \\
{[0.53]}\end{array}$ & $\begin{array}{l}0.055 \\
{[0.88]}\end{array}$ & $\begin{array}{r}0 \\
{[0.01]}\end{array}$ & $\begin{array}{r}0 \\
{[0.01]}\end{array}$ & $\begin{array}{c}-0.017 \\
{[0.17]}\end{array}$ & $\begin{array}{l}0.023 \\
{[0.24]}\end{array}$ \\
\hline liq & $\begin{array}{r}-0.019 \\
{[0.66]}\end{array}$ & $\begin{array}{r}-0.026 \\
{[0.90]}\end{array}$ & $\begin{array}{r}-0.006 \\
{[0.20]}\end{array}$ & $\begin{array}{c}-0.004 \\
{[0.14]}\end{array}$ & $\begin{array}{c}-0.004 \\
{[0.13]}\end{array}$ & $\begin{array}{r}-0.034 \\
{[1.02]}\end{array}$ \\
\hline fee & $\begin{array}{r}0.381 \\
{[2.06]^{*}}\end{array}$ & $\begin{array}{r}0.401 \\
{[2.13]^{*}}\end{array}$ & $\begin{array}{r}0.418 \\
{[2.27]^{*}}\end{array}$ & $\begin{array}{r}0.42 \\
{[2.29]^{*}}\end{array}$ & $\begin{array}{r}0.639 \\
{[1.98]^{\star}}\end{array}$ & $\begin{array}{l}0.623 \\
{[1.90]}\end{array}$ \\
\hline over & $\begin{array}{r}-0.298 \\
{[1.30]} \\
\end{array}$ & $\begin{array}{c}-0.321 \\
{[1.37]} \\
\end{array}$ & $\begin{array}{r}-0.389 \\
{[1.56]} \\
\end{array}$ & $\begin{array}{r}-0.39 \\
{[1.56]} \\
\end{array}$ & $\begin{array}{r}-0.551 \\
{[1.74]} \\
\end{array}$ & $\begin{array}{r}-0.492 \\
{[1.59]} \\
\end{array}$ \\
\hline $\mathrm{msl}$ & & $\begin{array}{r}0.077 \\
{[2.13]^{\star}}\end{array}$ & $\begin{array}{r}0.126 \\
{[3.13]^{\star \star}}\end{array}$ & $\begin{array}{r}0.124 \\
{[3.05]^{\star \star}}\end{array}$ & $\begin{array}{r}0.169 \\
{[3.86]^{\star *}} \\
\end{array}$ & $\begin{array}{r}0.135 \\
{[3.09]^{\star *}}\end{array}$ \\
\hline as & & $\begin{array}{r}-0.01 \\
{[2.07]^{*}}\end{array}$ & $\begin{array}{l}-0.012 \\
{[2.27]^{\star}}\end{array}$ & $\begin{array}{l}-0.012 \\
{[2.19]^{*}}\end{array}$ & $\begin{array}{c}-0.008 \\
{[1.37]} \\
\end{array}$ & $\begin{array}{r}-0.006 \\
{[1.01]}\end{array}$ \\
\hline ia & & & $\begin{array}{r}0.28 \\
{[4.13]^{\star \star}}\end{array}$ & $\begin{array}{r}0.274 \\
{[3.79]^{\star \star}}\end{array}$ & $\begin{array}{r}0.162 \\
{[2.26]^{\star}}\end{array}$ & $\begin{array}{l}0.107 \\
{[1.66]}\end{array}$ \\
\hline ef & & & & $\begin{array}{r}-0.007 \\
{[0.48]}\end{array}$ & $\begin{array}{r}-0.009 \\
{[0.36]}\end{array}$ & $\begin{array}{r}-0.022 \\
{[0.93]}\end{array}$ \\
\hline so & & & & & $\begin{array}{r}-0.227 \\
{[2.93]^{\star *}}\end{array}$ & $\begin{array}{c}-0.204 \\
{[2.82]^{\star *}}\end{array}$ \\
\hline actr & & & & & $\begin{array}{l}0.004 \\
{[0.47]}\end{array}$ & $\begin{array}{r}0.021 \\
{[2.18]^{*}}\end{array}$ \\
\hline ac & & & & & & $\begin{array}{r}-0.054 \\
{[4.30]^{\star \star}}\end{array}$ \\
\hline DLTIR & & & & & & $\begin{array}{l}0.236 \\
{[0.92]}\end{array}$ \\
\hline Constant & $\begin{array}{r}-0.049 \\
{[0.61]}\end{array}$ & $\begin{array}{l}0.072 \\
{[0.79]}\end{array}$ & $\begin{array}{r}-0.126 \\
{[1.13]}\end{array}$ & $\begin{array}{r}-0.109 \\
{[0.93]}\end{array}$ & $\begin{array}{r}-0.1 \\
{[0.79]} \\
\end{array}$ & $\begin{array}{r}-0.084 \\
{[0.68]}\end{array}$ \\
\hline Observations & 2014 & 2014 & 1585 & 1585 & 1340 & 1340 \\
\hline Number of Banks & 648 & 648 & 515 & 515 & 442 & 442 \\
\hline
\end{tabular}

Robust $\mathrm{z}$ statistics in brackets

* significant at $5 \%$; ** significant at $1 \%$ 
Table 9 -. Future Abnormal ROE: Non-Lineal Analysis

Non-Lineal Cross Sectional Regressions (pooled)

Dependent variable: Future $(\mathrm{t}+1)$ Abnormal ROE

\begin{tabular}{|c|c|c|c|c|c|c|}
\hline & Firm Level & $\begin{array}{l}\text { Industry: } \\
\text { Substitutes and } \\
\text { Threat of Entry }\end{array}$ & $\begin{array}{l}\text { Industry: } \\
\text { Rivalry between } \\
\text { Established } \\
\text { Competitors }\end{array}$ & $\begin{array}{l}\text { Industry: } \\
\text { Bargaining } \\
\text { Power of } \\
\text { Customers }\end{array}$ & $\begin{array}{l}\text { Industry: } \\
\text { Bargaining } \\
\text { Power of } \\
\text { Suppliers }\end{array}$ & $\begin{array}{l}\text { Economy: } \\
\text { Accounting } \\
\text { Conservatism and } \\
\text { Interest Rates }\end{array}$ \\
\hline \multirow[t]{2}{*}{$\overline{I I I p}$} & 0.02 & 0.02 & 0.002 & 0.001 & 0.023 & 0.021 \\
\hline & {$[0.36]$} & [0.35] & [0.03] & {$[0.01]$} & {$[0.37]$} & [0.33] \\
\hline \multirow[t]{2}{*}{ size } & -0.002 & -0.003 & -0.006 & -0.006 & -0.012 & -0.012 \\
\hline & {$[0.62]$} & [1.15] & {$[1.98]^{*}$} & [1.81] & {$[2.83]^{\star \star}$} & {$[2.81]^{\star \star}$} \\
\hline \multirow[t]{2}{*}{$\overline{\text { lev }}$} & 0.121 & 0.127 & 0.121 & 0.118 & 0.22 & 0.221 \\
\hline & [1.70] & [1.77] & [1.08] & [1.05] & [1.50] & [1.52] \\
\hline \multirow[t]{2}{*}{$\overline{\mathrm{mge}}$} & 0.113 & 0.116 & 0.178 & 0.17 & 0.177 & 0.175 \\
\hline & [1.62] & [1.66] & [1.95] & [1.89] & [1.49] & [1.46] \\
\hline \multirow[t]{2}{*}{ liq } & 0.036 & 0.034 & 0.013 & 0.012 & 0.023 & 0.018 \\
\hline & [1.67] & [1.54] & [0.48] & {$[0.42]$} & [0.75] & [0.57] \\
\hline \multirow[t]{2}{*}{ fee } & 0.12 & 0.121 & 0.195 & 0.2 & 0.232 & 0.241 \\
\hline & [1.04] & [1.05] & [1.28] & [1.33] & [0.82] & [0.84] \\
\hline \multirow[t]{2}{*}{ over } & 0.134 & 0.128 & 0.007 & -0.004 & -0.023 & -0.026 \\
\hline & {$[0.71]$} & {$[0.67]$} & {$[0.02]$} & {$[0.01]$} & {$[0.06]$} & [0.07] \\
\hline \multirow[t]{2}{*}{ ac } & 0.143 & 0.326 & 0.06 & 0.112 & 0.159 & 0.195 \\
\hline & [1.00] & [1.83] & {$[0.28]$} & {$[0.51]$} & [0.55] & [0.65] \\
\hline \multirow[t]{2}{*}{ acllip } & -1.261 & -1.095 & -0.908 & -0.788 & -0.608 & -0.648 \\
\hline & {$[3.65]^{\star \star}$} & {$[3.40]^{\star *}$} & {$[2.93]^{\star \star}$} & {$[2.62]^{\star \star}$} & {$[2.13]^{\star}$} & {$[2.27]^{*}$} \\
\hline \multirow[t]{2}{*}{ acsize } & -0.006 & -0.002 & 0.001 & 0.002 & 0.009 & 0.009 \\
\hline & [1.54] & {$[0.45]$} & {$[0.29]$} & {$[0.45]$} & [1.64] & [1.63] \\
\hline \multirow[t]{2}{*}{ aclev } & 0.081 & 0.129 & 0.326 & 0.284 & 0.096 & 0.105 \\
\hline & [0.59] & {$[0.89]$} & [1.46] & [1.22] & {$[0.38]$} & [0.41] \\
\hline \multirow[t]{2}{*}{ acmge } & -0.127 & -0.025 & -0.197 & -0.165 & -0.081 & -0.058 \\
\hline & [1.22] & {$[0.23]$} & [1.43] & {$[1.20]$} & {$[0.45]$} & [0.32] \\
\hline \multirow[t]{2}{*}{ acliq } & -0.163 & -0.18 & -0.105 & -0.052 & -0.118 & -0.112 \\
\hline & {$[2.92]^{\star \star}$} & {$[3.21]^{\star *}$} & [1.56] & {$[0.74]$} & [1.59] & [1.54] \\
\hline \multirow[t]{2}{*}{ acfee } & 1.424 & 1.622 & 1.355 & 1.29 & 1.327 & 1.447 \\
\hline & {$[3.53]^{\star \star}$} & {$[3.99]^{\star \star}$} & {$[2.55]^{*}$} & {$[2.44]^{*}$} & {$[2.29]^{*}$} & {$[2.39]^{*}$} \\
\hline acover & -1.342 & -1.557 & -1.339 & -1.294 & -1.28 & -1.378 \\
\hline & {$[3.16]^{\star *}$} & {$[3.62]^{\star *}$} & {$[2.29]^{*}$} & {$[2.26]^{*}$} & {$[2.10]^{\star}$} & {$[2.21]^{*}$} \\
\hline $\mathrm{msl}$ & & 0.039 & 0.066 & 0.06 & 0.165 & 0.164 \\
\hline & & [1.41] & {$[2.27]^{*}$} & {$[1.97]^{\star}$} & {$[4.85]^{\star \star}$} & {$[4.86]^{\star \star}$} \\
\hline as & & 0.005 & 0.011 & 0.01 & 0.025 & 0.027 \\
\hline & & {$[0.77]$} & [1.55] & [1.46] & {$[3.09]^{\star \star}$} & {$[3.25]^{\star \star}$} \\
\hline acmsl & & 0.112 & 0.169 & 0.128 & 0.049 & 0.051 \\
\hline & & [1.87] & {$[2.44]^{*}$} & [1.75] & {$[0.63]$} & {$[0.67]$} \\
\hline acas & & -0.025 & -0.034 & -0.026 & -0.048 & -0.051 \\
\hline & & {$[3.00]^{\star *}$} & {$[3.84]^{\star *}$} & {$[2.80]^{\star \star}$} & {$[4.37]^{\star \star}$} & {$[4.57]^{\star *}$} \\
\hline ia & & & -0.074 & -0.075 & -0.216 & -0.216 \\
\hline & & & [1.49] & [1.51] & {$[2.74]^{\star *}$} & {$[2.75]^{\star *}$} \\
\hline$\overline{\text { acia }}$ & & & 0.336 & 0.279 & 0.575 & 0.512 \\
\hline & & & {$[4.25]^{\star \star}$} & {$[3.39]^{\star \star}$} & {$[2.69]^{\star \star}$} & {$[2.33]^{\star}$} \\
\hline$\overline{\text { ef }}$ & & & & -0.014 & -0.011 & $\frac{1}{-0.016}$ \\
\hline & & & & [0.89] & {$[0.37]$} & [0.54] \\
\hline$\overline{\text { acef }}$ & & & & -0.063 & -0.021 & -0.001 \\
\hline & & & & {$[2.04]^{\star}$} & {$[0.44]$} & [0.02] \\
\hline so & & & & & -0.264 & -0.285 \\
\hline & & & & & {$[2.71]^{\star \star}$} & {$[2.89]^{\star \star}$} \\
\hline actr & & & & & 0.011 & 0.011 \\
\hline & & & & & [1.09] & [1.16] \\
\hline acso & & & & & 0.249 & 0.262 \\
\hline & & & & & [1.91] & {$[1.99]^{\star}$} \\
\hline acactr & & & & & -0.059 & -0.052 \\
\hline & & & & & [1.20] & [1.06] \\
\hline$\overline{\text { DLTIR }}$ & & & & & & -0.598 \\
\hline & & & & & & [1.36] \\
\hline acdltir & & & & & & 0.903 \\
\hline & & & & & & [1.76] \\
\hline Constant & -0.171 & -0.24 & -0.257 & -0.208 & -0.339 & -0.349 \\
\hline & {$[1.90]$} & [1.77] & {$[1.71]$} & {$[1.30]$} & {$[1.47]$} & [1.51] \\
\hline Observations & 2014 & 2014 & 1585 & 1585 & 1340 & 1340 \\
\hline R-squared & 0.08 & 0.1 & 0.15 & 0.16 & 0.2 & 0.2 \\
\hline
\end{tabular}

